\title{
Site-specific environmental impact assessment as a basis for supplier selections - exemplary application to aluminum
}

\author{
Schiessl, A. ${ }^{(a)}$; Müller, R. ${ }^{(a)}$; Volk, R. ${ }^{(a)}$; Schultmann, F. ${ }^{(a)}$ \\ (a) Karlsruhe Institute of Technology (KIT), Institute for Industrial Production (IIP) \\ Hertzstraße 16 \\ 76187 Karlsruhe \\ E-Mail:Andreas.schiess1@partner.kit.edu \\ Tel. + +49172 1643560 \\ ORCID: $\quad$ 0000-0003-1322-4778
}

\begin{abstract}
.
The commitment of international governments to limit global warming to $2^{\circ} \mathrm{C}$ has led to an increased awareness and interest in sustainability from various stakeholders. Especially the ecological performances of corporations and their products regarding limiting greenhouse gas emissions (GHG) receives increasing attention.

In Germany, almost $25 \%$ of the annual GHG emissions is generated by the industry - sector primarily for the respective raw material production. The production of aluminum, which is mainly used for applications in the mobility sector, accounts for $1 \%$ of the entire German GHG emissions. However, currently, the assessment focus is set on the vehicle use phase. And, so far little attention is paid on the material production where about $75 \%$ of the value adding process of a car takes place in upstream supply chains. Current supplier selection decision making is dominated so far mainly by cost and quality factors. To integrate $\mathrm{CO}_{2} \mathrm{e}$ as an additional decision criteria, comparable site-specific $\mathrm{CO}_{2} \mathrm{e}$ emission data from suppliers is essential, but currently not existent.

In order to close this gap, a model has been developed to assess the performance of raw material manufacturers on a site-specific level based on publicly available data only. The developed model is applied to all four primary aluminum manufacturing sites in Germany that produce via the electrolytic reduction of virgin aluminum oxide. The estimated site-specific results of the application range between 13,689 and $14,946 \mathrm{kgCO}_{2} \mathrm{e} /$ ton of raw aluminum and demonstrate different levels of internal process know-how, process integration and optimization in the production process of raw aluminum.

In consequence, there is an opportunity to reduce GHG emissions (up to $-8.4 \%$ ) for automotive and other manufacturing companies (e.g. the construction industry) by selecting more environmentally efficient suppliers for raw material and particularly aluminum.
\end{abstract}

Key words: $\mathrm{LCA}, \mathrm{CO}_{2} \mathrm{e}$, carbon footprint, aluminum industry, product assessment, supplier selection 


\section{Notation}

\section{Table 1: $\quad$ List of symbols}

\begin{tabular}{|c|c|c|c|}
\hline Symbol & Definition & Symbol & Definition \\
\hline$p s_{x, l}, x \in\{1 ; 4\}$ & $\begin{array}{l}\text { = number of process steps, respectively } \\
\text { intermediate products for aluminum } \\
\text { production (1: Anode factory, carbon anode; } 2 \text { : } \\
\text { electrolysis, liquid aluminum; } 3 \text { : casting plant, } \\
\text { raw aluminum; 4: rolling plant, aluminum } \\
\text { product) }\end{array}$ & $i p_{p s_{x}, l}^{\text {elect }}$ & $\begin{array}{l}=\text { average input factors for the electricity } \\
\text { amount per process [in GJ / t ] }\end{array}$ \\
\hline$l \in\{1 ; 4\}$ & $=$ number of locations & elect $_{p s_{x}, l}^{P V}$ & $\begin{array}{l}=\text { amount of electricity according to } \\
\text { production volumes [in GJ / a] }\end{array}$ \\
\hline$P V_{p s_{x}, l}$ & $=$ production volume $[$ in $\mathrm{t} / \mathrm{a}]$ & efact electmix $^{\text {ext }}$ & $\begin{array}{l}=\text { average country specific emission factor } \\
\text { for electricity production }\left[\text { in } \mathrm{tCO}_{2} / \mathrm{GJ}\right]\end{array}$ \\
\hline$C A P_{p s_{x}, l}$ & $=$ capacity per process step $[$ in $\mathrm{t}]$ & emiss $_{p_{s_{x}, l}}^{\text {elect }}{ }^{p v}$ & $\begin{array}{l}=\text { emissions from electricity according to } \\
\text { production volumes }\left[\text { in } \mathrm{tCO}_{2} / \mathrm{a}\right]\end{array}$ \\
\hline$m c r_{p s_{x}, p s_{x}}$ & $=$ average material conversion rates $[$ in $\mathrm{t} / \mathrm{t}]$ & $\operatorname{emiss}_{p s_{1}, l}^{\text {elect }}$ & $\begin{array}{l}=\text { emissions from electricity according to } \\
\text { additional production volumes }\left[\operatorname{in}\left[\mathrm{tCO}_{2} /\right.\right. \\
\text { a] }\end{array}$ \\
\hline emiss ${ }_{l}^{\text {reported }}$ & $=$ reported $\mathrm{CO}_{2}$ emissions $\left[\right.$ in $\left.\mathrm{tCO}_{2} / \mathrm{a}\right]$ & efact ${ }^{E U, C N}$ & $\begin{array}{l}=\text { mean value of the European and Chinese } \\
\text { emission factor for electricity production } \\
{\left[\text { in } \mathrm{tCO}_{2} / \mathrm{GJ}\right]}\end{array}$ \\
\hline emiss $_{p s_{x}, l}^{p v}$ & $\begin{array}{l}=\text { allocated emissions according to production } \\
\text { volumes }\left[\mathrm{in} \mathrm{tCO}_{2} / \mathrm{a}\right]\end{array}$ & emiss $_{p s_{x}, l}^{\text {elect }}{ }^{\text {adjusted }}$ & $\begin{array}{l}d=\text { adjusted emissions from electricity } \\
{\left[\operatorname{in}\left[\mathrm{tCO}_{2} / \mathrm{a}\right]\right.}\end{array}$ \\
\hline$e f a c t t_{p s_{x}, l}^{l o c a l}$ & $=$ local, process step related emission factors & emiss $_{l}^{\text {reported }}{ }^{p f c}$ & $=$ reported PFC emissions $[$ in $\mathrm{t} / \mathrm{a}$ ] \\
\hline efact $_{p s_{x}}$ & $\begin{array}{l}=\text { industry average emission factors for process } \\
\text { steps }\left[\text { in } \mathrm{tCO}_{2} / \mathrm{t}\right]\end{array}$ & efact ${ }_{\emptyset}^{p f c}$ & $\begin{array}{l}=\text { industry average emission factors for } \\
\text { PFC emissions }\left[\text { in } \mathrm{tCO}_{2} / \mathrm{t}\right]\end{array}$ \\
\hline emiss $_{p s_{x}, l}^{\text {theor }}$ & $=$ theoretical emissions $\left[\right.$ in $\left.\mathrm{tCO}_{2} / \mathrm{a}\right]$ & $\operatorname{emiss}_{l}^{p f c}$ & $=\mathrm{PFC}$ emission $\left[\right.$ in $\left.\mathrm{tCO}_{2} / \mathrm{a}\right]$ \\
\hline$P V_{p s_{3}, l}^{\text {theor }}$ & $=$ theoretical production volume $[$ in $\mathrm{t} / \mathrm{a}]$ & emiss urmsc & $\begin{array}{l}=\text { average emissions for upstream raw } \\
\text { material supply chain input }\left[\text { in } \mathrm{kgCO}_{2} / \mathrm{a}\right]\end{array}$ \\
\hline$A P V_{p s_{x}, l}$ & $=$ additional production volumes $[$ in $\mathrm{t} / \mathrm{a}]$ & emiss $_{l}^{\text {total }}$ & $\begin{array}{l}=\text { total emissions per production site [in } \\
\mathrm{kgCO}_{2} \mathrm{e} / \mathrm{t} \text { raw aluminum] }\end{array}$ \\
\hline $\operatorname{emiss}_{p s_{x}, l}^{a p v}$ & $\begin{array}{l}=\text { emission of additional production volumes } \\
{\left[\mathrm{tCO}_{2} / \mathrm{a}\right]}\end{array}$ & $\tilde{x}$ & $=$ auxiliary variable and corresponds to $x$ \\
\hline emiss ${ }_{p s_{\chi}, l}^{\text {adjusted }}$ & $=$ adjusted emissions $\left[\right.$ in $\left.\mathrm{tCO}_{2} / \mathrm{t}\right]$ & & \\
\hline
\end{tabular}

\section{Introduction}

The significant growth of greenhouse gases $(\mathrm{GHG})$ in the atmosphere of the earth is considered as one crucial trigger of global warming, which has shown recognizable effects on climate change in the last 
century (IPCC, 2013). As a consequence, international governments have united and reached a binding agreement to limit global warming to $2^{\circ} \mathrm{C}$ and to even foster activities to reach a maximum global warming of $1.5^{\circ} \mathrm{C}$ (European Commission, 2015).

One key GHG contributor is the metal industry accounting for approximately $21 \%$ of the global greenhouse gas emissions (expressed in carbon dioxide equivalents $-\mathrm{CO}_{2} \mathrm{e}$ ), of which $1 \%$ is caused by the aluminum production industry (EPA, 2016; Gautam et al., 2018). The very energy intensive production process is highly depending on electricity (on average $15 \mathrm{kWh}$ per kg produced aluminum in Europe), and accounts for $80 \%$ of the GHG emissions in aluminum production (IPCC, 2014). In comparison to steel, aluminum has a 4.58 times higher carbon footprint, taking global average values for basic oxygen steel $\left(2,380 \mathrm{tCO}_{2} /\right.$ t) and primary aluminum ${ }^{1}$ production $\left(13,930 \mathrm{tCO}_{2} / \mathrm{t}\right)$ into consideration (Egede, 2016). Over the last decade, the European aluminum production for aluminum has grown by roughly $7 \%$ to a total production volume of 11,100 thousand metric tons in 2018 (World Bureau of Metal Statistics, 2019a, 2019b). In Germany, the production volume of the aluminum industry has however significantly increased (51.4\% growth from 2009 to 2018), and represents an European share of 11.66\% (World Bureau of Metal Statistics, 2019a, 2019b). The aluminum production sector alone accounts for $1 \%$ of the overall German GHG emissions (BMWi, 2020).

Almost half of the aluminum produced in Germany is used in various applications in the mobility sector (WMV, 2019). This is related to the increased usage of aluminum in the production of passenger vehicles in Europe, which has grown from by $80 \%$ approximately $32 \mathrm{~kg}$ (in 1978) to $160 \mathrm{~kg}$ per vehicle (in 2015) (GDA, 2015). However, in automotive supply chains, currently little consideration is given to GHG emissions created in the manufacturing phase. The focus lies almost exclusively on the usage phase which is already regulated by the European Commission (European Commission, 2009, 2019b). The European Political Strategy Center, which can be considered as the in-house think tank of the European Commission, has already started first discussions on future activities in terms of embedded emissions for the vehicle manufacturing phase (EPSC, 2016). Only recently, first proactive initiatives in the automotive industry, such as the Volkswagen ID project, take the emissions from the entire product lifecycle (including the manufacturing phase) into account and aim at carbon-neutrality per produced vehicle (Volkswagen AG, 2019).

As approximately $75 \%$ of the value adding processes in automotive value chains are performed by upstream suppliers (Bai and Sarkis, 2011; Hartley and Choi, 1996) the focus needs to be directed towards the procurement from these companies. Thus, from a purchasing perspective, the selection of more

\footnotetext{
${ }^{1}$ The term primary aluminum refers in this study to aluminum produced by means of electrolytic reduction of virgin aluminum oxide (European Environment Agency, 2019a).
} 
environmentally efficient suppliers for raw material and particularly aluminum is an opportunity to reduce the carbon footprint of automotive and other manufacturing companies (e.g. the construction or aviation industry) and thus for industrial sector as a whole. In pursuit of this goal, a greater transparency of environmental performance of suppliers' production processes on a site-specific level is required, which is presently lacking. In the aluminum industry, this lack of data transparency and the limited accessibility of primary data on a site-specific level is owed to industrial secret. The life cycle analysis method (LCA) has been frequently used to determine $\mathrm{CO}_{2} \mathrm{e}$ emissions in the aluminum industry. However, two shortcomings in the application of LCA in the aluminum industry exist: the missing standardization in setting system boundaries, and thus lacking comparability, and the consultation of average industry data in order to replace unavailable prima data which also hampers comparability. Particularly, comparability of production sites is currently not possible. Hence, this study develops an approach to close this gap and to consequently create the data basis and methodological background for a comparable LCA analyses and assessments between specific aluminum production sites and a consequent, practical integration of $\mathrm{CO}_{2} \mathrm{e}$ as additional criteria in procurement decision-making.

In the following, a review of related literature is presented (section 2) and the research approach is sketched (section 3). The results of an exemplary case study application on four German primary aluminum sites ${ }^{2}$ are illustrated in section 4. Finally, a discussion and conclusion is given in section 5.

\section{Literature review}

\subsection{Life-cycle assessment for environmental performance evaluation}

The interest in assessing the environmental impacts of products or services has notably grown over the last decades (Bilec et al., 2006; Guinée et al., 2011). In this regard, life cycle analysis (LCA) has found broad application both in corporate and in governmental context (Beaussier et al., 2019; Breun, 2016; Hendrickson et al., 1997; Zamagni et al., 2013). In a holistic approach, LCA comprises the quantification of environmental effects and consequential burdens of the entire product or process life cycle starting from the original raw material extraction to the recycling or disposal at the end-of-life stage (Guinée et al., 1993; Hendrickson et al., 1997; Kndungu and Molavi, 2014; Roy et al., 2009; Sonnemann et al., 2004; Suh et al., 2004). In the ISO standard 14040, the principles as well as a standardized guidance for the conduction of LCA is defined (International Standards Organisation, 2006a). In addition, ISO 14044 provides a set of standardized requirements, which form the foundation of LCA studies (International Standards Organisation, 2006b). The suggested process is structured in four stages: goal and scope definition, life cycle inventory analysis (LCI), life cycle impact assessment (LCIA) and the interpretation stage. In general,

\footnotetext{
${ }^{2}$ Site, plant and location are used synonymously in the following.
} 
two approaches can be distinguished, depending on the intended target of application: attributional and consequential LCA. In attributional LCAs, an isolated product system is described with reference to the material and energy flows which are directly linked to a defined inventory within the defined system boundary. On the contrary, in consequential LCAs, the focus lies on the quantification of emission changes, which consequently result of decisions and related actions (Brander, 2017; Weidema, 1993, 2003), e.g. investments. Both approaches can be used either retrospectively for the assessment of past actions or prospectively for the assessment of possible future actions.

In scientific literature, three LCA methods are distinguished: the process method (bottom-up), the inputoutput analysis (top-down) and hybrid methods. The process method is based on the determination of all product specific input output flows (material and energy flows) by means of a flow diagram according to a defined functional unit (Kndungu and Molavi, 2014; Sonnemann et al., 2004). The input-output approach makes use of national, economic input-output data combined with environmental impacts at sector level, while an interdependency of economic sectors is presumed (Leontief, 1970). Besides a variety of advantages, the two methods come along with some disadvantages. In the process method, the nonstandardized definition of system boundaries, the high level of detail required in terms of data and the consequent high effort for data gathering can illustrate a drawback (Bilec et al., 2006; Guinée et al., 1993; Hendrickson et al., 1997; Yellishetty et al., 2011). Therefore, LCA databases relying on industry average data, as for example GaBi or ecoinvent (Ecoinvent, 2007-2013; Gabi, 2017), are often consulted in the process method. In contrast, the input-output analysis with an entire economy as system boundary provides a too aggregated level of detail and sectoral level only (Bilec et al., 2006; Suh et al., 2004; Zimmer et al., 2017). In order to overcome the listed drawbacks, hybrid approaches aiming at combining the advantages of both methods are developed more frequently (Guinée et al., 2011).

The study aims at comparing the environmental performance of different primary aluminum sites; thus, the process method is not suitable due to unavailable public site-specific primary data. The use of industrial average data from LCA databases or of the sectoral input-output approach are also impossible, due to the high level of data aggregation.

\subsection{Life-cycle assessment in the aluminum industry}

Several publications have been published on the environmental impact assessment of the aluminum production process by means of life cycle analysis. Tan and Khoo (2005) conducted a cradle-to-gate LCA for the primary aluminum industry in Australia with a focus on a refinery, a smelter and a casting plant. They analyzed the environmental impact via global warming potential (GWP), human toxicity for air (HTA), bulk wastes and acidification (Ac) with SimaPro LCA software in four scenarios based on 
technological approaches and sustainable practices to improve the production process and thus reduce the environmental impact.

Similarly, Norgate et al. (2007) used LCA to assess the environmental impact of metal production processes in Australia. Among others, the environmental impact of Aluminum was investigated in a cradle-to-gate consideration, relying on various non-disclosed literature sources. The study covers the two impact categories of acidification gas emissions (Acidification Potential, AP) and greenhouse gas emissions (expressed in GWP).

Ciacci et al. (2014) combined life cycle analysis and material flow analysis (MFA) in order to analyze the GHG emissions in the aluminum industry in Italy. In a cradle-to-gate approach the development of the environmental impact (GWP) is analyzed on country level over a period of approximately 50 years (1960 until 2009) in order to provide support for political stakeholders for the orientation of industrial policies towards cleaner manufacturing of aluminum. Data on a national level was retrieved from the Italian Institute for Environmental Protection and Research (ISPRA), the Italian electricity transmission grid operator TERNA, from the International Aluminium Institute, the European Aluminum Association and the International Energy Agency was used in conjunction with primary information from expert consultation.

Similar to the study of Ciacci et al. (2014), Suciati and Goto (2014) applied a combination of MFA and LCA for the evaluation of the environmental impact of the primary aluminum production in Indonesia. They analyze the current situation and provide future projections on carbon dioxide emissions $\left(\mathrm{CO}_{2}\right)$ in reference to the Indonesian roadmap for national aluminium development. Therefore, they assess $\mathrm{CO}_{2}$ emissions in a cradle-to-gate scope. The used data is mainly derived from the Statistical Yearbook of Indonesia and on unspecified literature sources as well as publicly available reports.

Kornelíusdóttir (2014) conducted and compared two cradle-to-gate LCAs (reference year 2012) for an average European smelter and for the aluminum production process at the Norðurál plant in Iceland. The necessary inventory data for the site-specific consideration is composed of publicly available data as well as internal information from Norðurál, supplemented by information from the Environmental Agency of Iceland. For the calculation of the average European smelter, an industry average dataset provided by the European Aluminium Association is consulted. The GaBi LCA software is used for the impact assessment based on the CML 2001 methodology assessing GWP and six other impact categories.

Kovács and Kiss (2016) carried out a comparative analysis based on LCA in order to reveal the GWP hotspots in the aluminum production process. In a simplified cradle-to-gate consideration, the process steps of bauxite mining as well as alumina refining, production of anode, aluminum smelting, ingot casting and power generation are investigated for the reference year 2010. The examination is based on two type of anodes used for the aluminum production: conventional (Soderberg and prebake) and inert anodes. 
Additionally, a scenario analysis with eight scenarios is conducted applying either fossil, coal-based energy supply or a renewable energy mix with hydro power being the key source. The life cycle inventory comprises average data from LCA studies of the International Aluminium Institute, the Aluminium Association and the European Aluminium Association in general. For the scenario analysis, exemplary the composition of the fossil energy mix is taken from China and for the hydro based energy mix the Canadian composition is consulted. In addition, company-specific data from the Russian aluminum manufacturer Rusal is used for the calculation of the production process of inert anodes and applied in the scenarios. The impact assessment is based on the CML method with emphasis on GWP and primary energy demand (PED).

Nunez and Jones (2016) performed a LCA to test and challenge the LCI data published by the International Aluminium Institute and to emphasize the need for up-to-date and robust data sets for practitioners in general. The study relies exclusively on average industry data for direct process steps. The data set is supplemented with average background data from the GaBi database for indirect processes. In a cradle-togate model, the environmental impact of the primary aluminum production is evaluated with datasets on a global level and on an adjusted, so called rest of the world level without China. The LCIA comprises six CML midpoint impact categories: GWP, ozone depletion potential, acidification potential, depletion of fossil energy resources, photo-oxidant creation potential and eutrophication potential.

Paraskevas et al. (2016) applied the LCA method to assess and compare the environmental performance of primary aluminum production on national level. The scope comprises 29 countries which are particularly active in the aluminum production business and reaches from raw material mining, via refining to primary aluminum smelting. The comparison among investigated countries focuses on the underlying energy mix as well as the technology mix. The inventory data for the reference year 2012 is derived from publicly available sources such as the United States Geological Survey (USGS), the ecoinvent database and the International Energy Agency's (IEA). The impact assessment, which is performed in the SimaPro software, concentrates on the midpoint indicator GWP and is based on the ReCiPe method.

Yang et al. (2019) carried out a LCA for the primary aluminum production process in China relying on the lime soda Bayer process. The study with reference year 2017 concentrates on two modes of energy inputs' for power generation: thermal power and hydropower. It covers the processes from bauxite mining to ingot casting but explicitly excludes transportation. The underlying inventory data for direct processes is derived from company-specific field surveys and other, not disclosed information from the aluminum industry in China. For the evaluation of indirect processes, average data from China's Life Cycle Database (CLCD) and the online LCA tool eFootprint, developed by IKE Environmental Technology Co. Ltd. is consulted. In terms of environmental impact assessment, they focus on four of the 13 impact categories from the product environmental footprint (PEF) methodology: GWP, primary energy demand (PED), freshwater eutrophication potential (FEP) and water use (WU). 
Farjana et al. (2019) analyzed the environmental impact of the aluminum production process in the United States by means of LCA within the scope of the defined cradle-to-gate system boundary. Average data from the ecoinvent database is consulted for the inventory analysis. Various impact categories (ozone formation, GWP, eutrophication, acidification, human toxicity and ecotoxicity) were assessed by the SimaPro software using the International Life-cycle Reference Data System method (ILCD), the Tool for Reduction and Assessment of Chemicals and Other Environmental Impacts method (TRACI) and the Cumulative Energy Demand method (CED). In addition, Farjana et al. (2019) conducted a sensitivity analysis based on a variety of scenarios in order to analyze how the type of fuel as energy input for the aluminum production process affects the overall environmental impacts.

In contrast to the reviewed retrospective approaches above, Schmidt and Thrane (2009) conducted a prospective LCA to analyze the future environmental impact of a planned aluminum smelter in Greenland. The cradle-to-gate analysis is conducted in SimaPro software and is based on company-specific data from Alcoa complemented with average industry data from the European Aluminium Association (EAA). In accordance with the requirements of the Government of Greenland, the study provides decision support in terms of granting or not granting approval for the launch of a new smelter.

Liu and Müller (2012) reviewed diverse LCA studies (36 peer-reviewed publications and gray literature studies) in order to analyze and discuss the current state of practice as well the weaknesses and strengths of LCA for the evaluation of aluminum production. Special emphasis is put on the limited scope of geographical coverage, the definition of scope, the setting of system boundaries and the practical use of average industry data. The examined widespread range of results (5.92 to $41.10 \mathrm{kgCO}_{2} \mathrm{e} / \mathrm{kg}$ primary aluminum) can be traced back to not only temporal and geographical factors but also data uncertainties and varying method applications (e.g. with respect to definitions of system boundaries, inventory data sources, technological assumptions and types of allocation methods).

Das (2014) uses LCA to model the effects of different material compositions of passenger vehicles' components from an environmental impact perspective. For this, cradle-to-gate LCAs for steel and aluminum were conducted according to the ISO standards 14040 and 14044, within the geographical scope of North America. Das (2014) relies on primarily North American average data from 2010, which is derived from the Steel Recycling Institute, the Aluminum Association, the U.S. Environmental Protection Agency and the ecoinvent data base.

The presented models and methods exhibit different strengths and weaknesses, which are discussed in the following with respect to the categories of 'site-specific transparency and assessment', 'comparability and widespread application', as well as 'availability of data and model complexity'. With regard to the 'sitespecific transparency and assessment' several models using life cycle analysis were presented. However, 
they show different emphases. Only two publications (Kornelíusdóttir, 2014; Schmidt and Thrane, 2009) concentrate on a company-specific level. Kornelíusdóttir (2014) follow a plant specific consideration for one site exclusively in order illustrate the differences of this plant in comparison to the average values of European production sites, e.g. available in ecoinvent or similar databases. Schmidt and Thrane (2009) conducted a prospective LCA of one planned and still not existing production site with the goal to evaluate the future environmental impact and thus support decision makers in the project approval process. In the 'site-specific transparency and assessment' aspect, the application of results for supplier selection decisions strongly depends on a 'comparability' of the defined system boundaries of the product system and a facilitation for a 'wide-spread application'. Only Paraskevas et al. (2016) aims at assessing and comparing the environmental performance of primary aluminum production, but only on national instead of production site level.

None of the reviewed models allows for a comparison of various aluminum production sites. They are either too specifically tailored to the production process of a certain plant or too general or aggregated on a regional or national level. Regarding the 'availability of data and model complexity', the discussed approaches show high variances: Whereas the approaches developed by Kornelíusdóttir (2014) and Schmidt and Thrane (2009) focus on a site-specific environmental impact assessment their results are not transparent, due to the undisclosed primary data underlying their calculation/assessment. The same applies to the LCA model from Yang et al. (2019) which primarily relies on not disclosed information retrieved from company-specific field surveys. The majority of the identified approaches, such as from Norgate et al. (2007), Ciacci et al. (2014), Suciati and Goto (2014) and Farjana et al. (2019) with a regional focus (Australia, Italy, Indonesia and USA) emphasize the estimation of environmental impact of aluminum production based on an average industrial data. This is also the case for the approaches of Liu and Müller (2012) and Das (2014), which discuss rather general topics in the area of LCA, such as for example the general applicability of LCA for the assessment of aluminum production (Liu and Müller, 2012) or the environmental effects on a product based on different material selections (Das, 2014).

Hence, the existing approaches do not provide site-specific LCA to enable a comparability of production sites' LCA results and their production efficiencies. Thus, a decision support for purchasing decisions with respect to GWP is lacking, yet. This study aims at closing this research gap to enable a widespread national and international comparability among manufacturers on a site-specific level. 


\section{Model for the assessment of site-specific environmental performance for aluminum}

\subsection{Model structure and concept}

A technical assessment model was developed to create transparency of environmental performance of primary aluminum manufacturers' production processes which allows for a comparability of different production sites. The major steps include definition of assessment scope and system boundaries, data collection, assessment of the combined process LCA and the estimation of site specific GWP (see Figure 1, 'sub-model for environmental performance assessment'). These steps follow the assessment approach for steel production recently published by Schiessl et al. (2020) and can be considered as a transfer of the standardized procedure to a different material commodity production. This transfer requires adjustments of the developed approach based on specific characteristics of the production process for aluminum, a different level of process complexity and the additional consideration of potent greenhouse gases (perfluorocarbon emissions), which are elaborated in this study. Similar to Schiessl et al. (2020) the systematic and modular LCA based approach of this study - $\mathrm{ECCO}_{2}$ aluminum (evaluation tool to compare $\mathrm{CO}_{2}$ emissions of the aluminum industry) - relies on the combination of a bottom-up calculation of technical process flows with top-down, site-specific environmental performance information, $\mathrm{CO}_{2}$ emissions and is based exclusively on the usage of publicly available data. Due to the missing data availability and granularity, the singular conduction of a bottom-up material flow calculation along the production process on a process step level based on a process LCA does not provide the possibility to create site specific performance results. The combination with a top-down integration of site-specific process-related $\mathrm{CO}_{2}$ emissions, which are publically reported, however helps to overcome this hurdle as by this means, varying site specific process improvement respectively efficient measures, representing the core competencies of production sites and are therefore highly confidential, are integrated in the results (see section 3.2.5). 


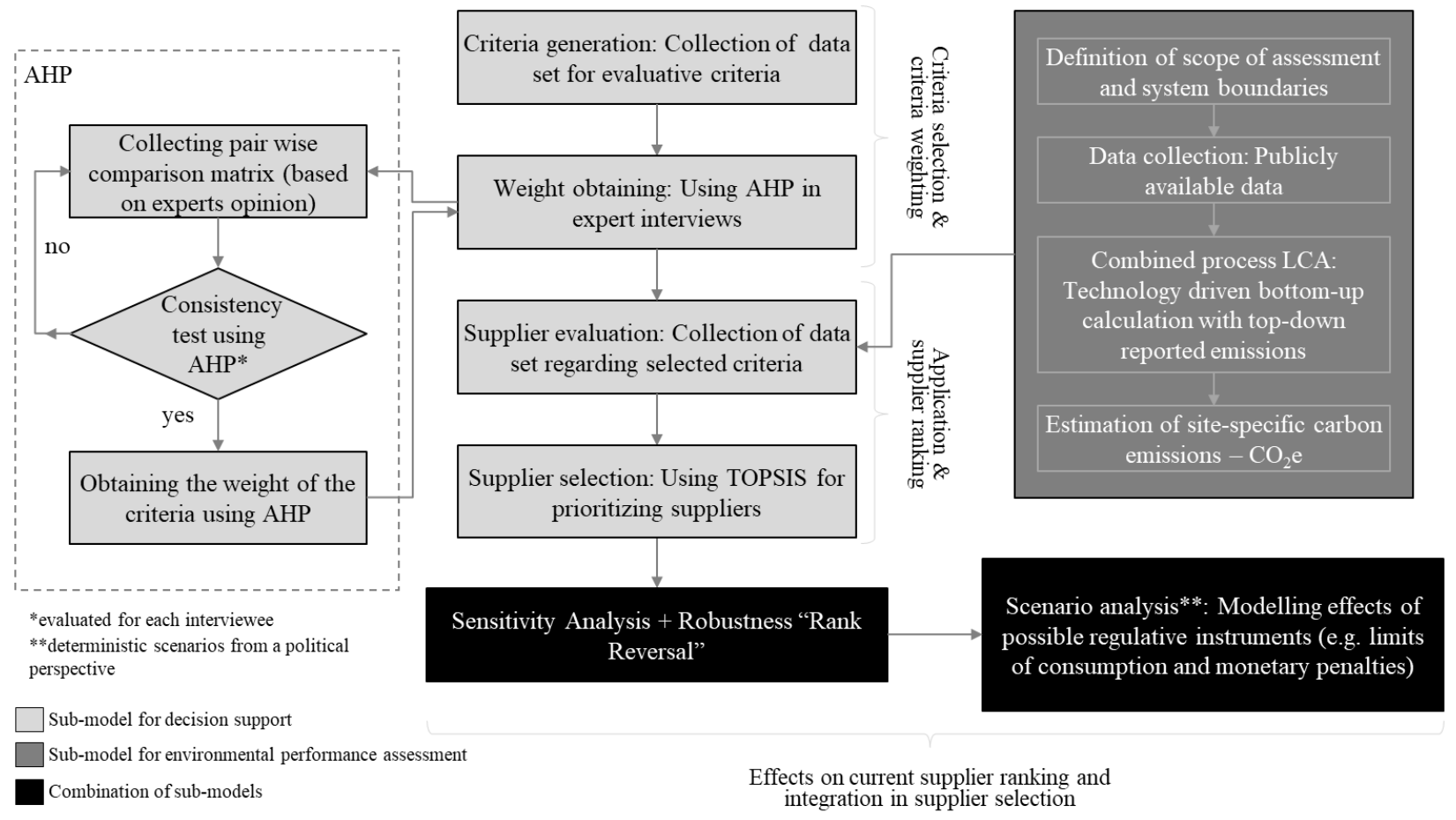

Figure 1: $\quad$ Structure of the outlined model to assess site-specific $\mathrm{CO}_{2}$ e performance (based on Schiessl et al. (2020))

The sub-model for environmental performance assessment, displayed on a dark gray background in Figure 1 , relies on the newly developed model for the technical assessment of aluminum production technologies (see section 3.2.5). A more detailed illustration of the approach can be found in Figure 4.

\subsection{Model development}

\subsubsection{Process steps in the manufacturing process of a primary aluminum plant (electrolysis)}

The manufacturing process of primary aluminum products consists of five principle process steps $\left(p s_{x}\right)$ : alumina production (Bayer process) $\left(p s_{0}\right)$, anode production $\left(p s_{1}\right)$, electrolysis (Hall-Héroult process) $\left(p s_{2}\right)$, casting $\left(p s_{3}\right)$ and further processing $\left(p s_{4}\right)$. (European Commission, 2014, 2017; European Environment Agency, 2019a). In Figure 2, the production process is illustrated and shows the major assessment model parts and the accordingly considered process steps.

The production of primary aluminum relies on the natural source material bauxite, an aluminum rich mineral occurring mainly in Australia, China, Guinea, Brazil and India (U.S. Geological Survey, 2020), which is further preprocessed to alumina in the Bayer process and to the hazardous by-product red mud (bauxite residues). At primary aluminum production sites, the alumina is poured in electrolytic reduction cells $\left(p s_{2}\right)$ filled with a high-temperature molten cryolite bath (approximately $960{ }^{\circ} \mathrm{C}$ ). By the induction of electric currents, the oxygen and aluminum atoms are separated and result in liquid aluminum. These cells consist of carbon cathodes which are located in a rectangular steel shell and isolated by refractory brick walls inside 
as well as carbon anodes which are suspended and hold in place by electrically conductive anode beams. In the process, oxygen is extracted from alumina by a chemical reaction with the positive carbon anodes, which are thus continuously consumed and emit carbon dioxide as well as monoxide during the reaction. The positive aluminum ions are attracted to the negative carbon cathodes forming pure aluminum. In modern plants, the anodes are produced by the prebake technology relying on calcined petroleum coke, coal tar pitch and anode butts. They, are either produced in an adjoining anode factory onsite $\left(p s_{1}\right)$ or are externally purchased. From an environmental and particularly climate change perspective, especially the anode effect is critical. The anode effect describes when the alumina content in the electrolytic bath decreases below 1$2 \%$ and thus instead of a decomposition of alumina, cyrolite decomposes into metal and fluoride ions which react with the carbon anodes and lead to a formation of gaseous perfluorocarbon emissions (PFC). The molten aluminum will be periodically tapped by vacuum siphons and transported in crucibles to the casting plants, where it is formed to ingots $\left(p s_{3}\right)$. During the casting process, the pure aluminum can also be refined according to the metallurgical properties required by the customer, by the addition of master alloying elements (such as Ti, Cr, Fe, Mn, Ni) or metals (such as $\mathrm{Si}, \mathrm{Mg}, \mathrm{Pb}, \mathrm{Sn}, \mathrm{Zn}, \mathrm{Cu}, \mathrm{Zr}$, Sr). After the casting process, the produced aluminum can additionally be formed and processed according to the customer requirements, for example in rolling plants $\left(p s_{4}\right)$. 


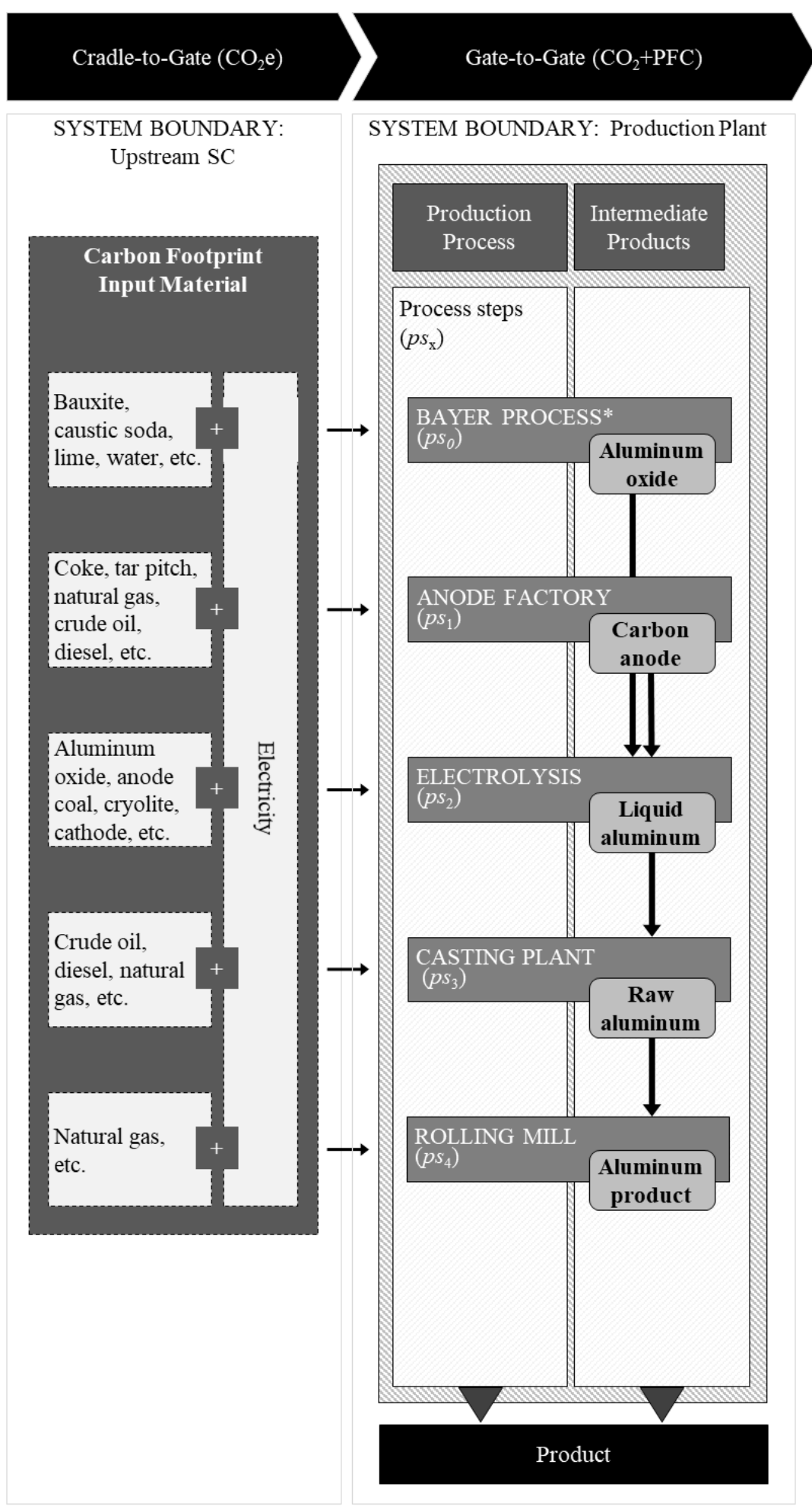

*The Bayer process is not conducted on-site at the examined primary aluminum production plants. The respective emissions are however considered in the model within the 'Upstream SC' system boundary.

Figure 2: $\quad$ Process steps of a primary aluminum plant including designated system boundaries and the contemplated material flows 


\subsubsection{Scope of the site-specific $\mathrm{CO}_{2}$ e approach and functional unit}

As carbon emissions represent the largest share of all GHG emissions in the non-ferrous metal industry, $97.22 \%$, the scope in this study was accordingly defined on $\mathrm{CO}_{2}$ emissions (UBA, 2019a). This includes process-related emissions which are directly created during the aluminum production process at the site (Scope $1^{3}$ ) and indirect, energy-related emissions (Scope 2) which are released during the electricity production that is hence consumed in the manufacturing process. Additionally, perfluorocarbons (PFC), which are formed during the anode effect in the electrolysis are also incorporated into the scope of the

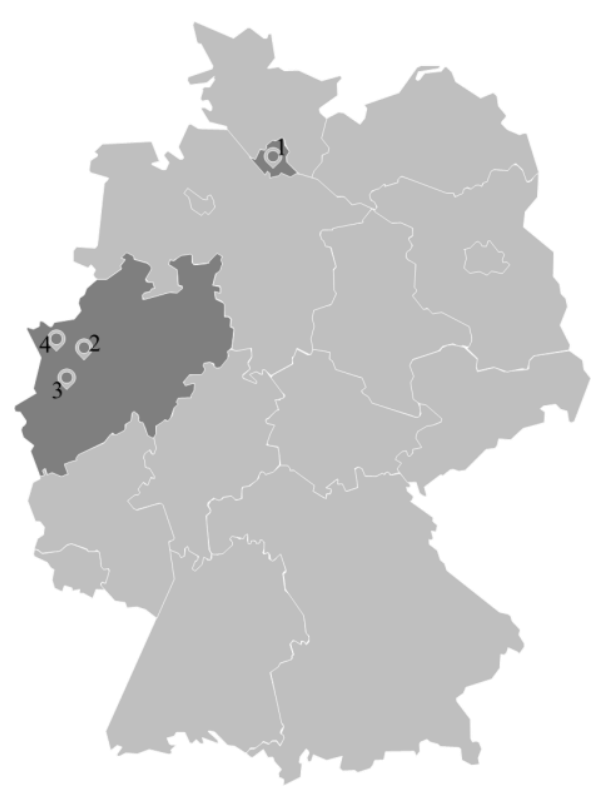

Figure 3: $\quad$ Geographic location of the considered primary aluminum plants in Germany model. During this reaction very potent and stable greenhouse gases $\mathrm{CF}_{4}$ (tetrafluoromethane) and $\mathrm{C}_{2} \mathrm{~F}_{6}$ (hexafluoroethane) are formed in an approximate ratio of 10:1 (Ecofys, ISI, Öko-Institut, 2009; European Commission, 2014) that are covered in the Kyoto protocol and included in the assessment. The powerfulness of PFCs in terms of environmental impact is clearly evident considering the global warming potential (GWP) with a 100-year time horizon for $\mathrm{CF}_{4}$ of 7,390 $\mathrm{tCO}_{2} \mathrm{e} / \mathrm{t}$ raw aluminum and for $\mathrm{C}_{2} \mathrm{~F}_{6}$ of $12,200 \mathrm{tCO}_{2} \mathrm{e}$ I t raw aluminum (IPCC, 2007).

Finally, all greenhouse gases resulting from upstream supply chain activities (Scope 3) were also considered. Resulting from the consultation of the same automotive expert group as for the development of the steel model (Schiessl et al., 2020), the geographic focus was laid on the four primary aluminum sites in Germany (see Figure 3).

In order to carry out a normalization of the LCI dataset (Roy et al., 2009), the functional unit was determined as one $\mathrm{t}$ of raw aluminum. This is a crucial performance measure in LCA which enables a comparability among aluminum producers (Bieda et al., 2015; International Standards Organisation, 2006b; Kndungu and Molavi, 2014), as raw aluminum represents the output product of the examined aluminum plants.

\footnotetext{
${ }^{3}$ The consulted classification in scopes 1-3 relies on the GHG Protocol Corporate Standard, which provides a guidance for organizations to prepare emission inventories (Scope 1: direct emissions from company owned sources, Scope 2: indirect emissions from purchased energy and Scope 3: indirect emissions from value chain activities (GHG Protocol $(2004,2013))$.
} 


\subsubsection{System boundaries}

In combination with the functional unit, the system boundaries of this study were set to enable a comparability among the results per site (see Figure 2) and to fit complementarily to the steel assessment in Schiessl et al. (2020). It comprises all onsite operations for the production of primary aluminum within the gate-to-gate boundaries "Production Plant". The system under study is furthermore extended to a cradle-togate consideration of the "Upstream supply chain SC" by means of industrial average emission data for upstream input material based on ecoinvent data (Ecoinvent, 2007-2013) due to a non-availability of sitespecific information. The process flow diagram of the aluminum production, illustrated in Figure 2, summarizes all assessed process steps, emissions and external supplies which impact the site-specific $\mathrm{CO}_{2} \mathrm{e}$ emissions in this study.

\subsubsection{Data collection}

A comprehensive data gathering process was conducted in the life cycle inventory phase (International Standards Organisation, 2006a), which is the basis for an assessment of the environmental impact on a sitespecific level.

As the access to primary data is very restricted in the aluminum industry, the focus was laid on the collection of regularly updated and publicly available data sources (reference year of $2012^{4}$ ). This enables a continuous extension of the time horizon under study. In comparison to the data collection process carried out for the assessment of steel manufacture sites (Schiessl et al., 2020), the availability of public data is even more constricted in the aluminum industry and thus, the data gathering was more effortful.

Similar to the regulations valid for the steel industry, each primary aluminum producing plant is required to apply for and receive permission for operation according to Industrial Emissions Directive 2010/75/EU (European Commission, 2010). Accordingly, the best available techniques (BAT) reference document for the non-ferrous metal industry applies (European Commission, 2014, 2017). In this study, the BAT reference document, which was co-developed by the European Aluminium Association and its industrial members (European Aluminium, 2019; European Commission, 2017), the Environmental Profile Report (European Aluminium, 2013) and the publicly available site-specific data (see Table 2) serve as basis for the bottom-up, technology-driven assessment (see section 3.2.5).

The obligation to report emissions to the European parliament and the council according to EC regulation No 166/2006 (European Commission, 2006) also requires member states to report the release of air pollutants from the aluminum producing industry. More specifically, the electrolytic production of nonferrous crude metals and the production of graphite anodes (see section 3.2.1) are included, which represent

\footnotetext{
${ }^{4}$ The reference year 2012 was chosen with regard to the data availability and the harmonization and comparison with the steel model published in Schiessl et al. (2020).
} 
the fundamentals for the top-down incorporation of the reported site-specific emissions (see section 3.2.5). Additional information about the data used is provided in the Appendix.

Table 2: $\quad$ Data sources applied

\begin{tabular}{|c|c|c|}
\hline Data Scope & Type of data & Source \\
\hline \multirow[t]{5}{*}{ Plant specific data } & \multirow[t]{3}{*}{ Capacities } & Federal activity reports $(\mathrm{BGR}, 2012)$ \\
\hline & & $\begin{array}{l}\text { International area reports - Minerals Yearbook (U.S. } \\
\text { Geological Survey, 2013, 2015) }\end{array}$ \\
\hline & & Company specific reports \\
\hline & Production Volumes & Company specific reports \\
\hline & Emissions & $\begin{array}{l}\text { European Pollution and Transfer Register E-PRTR } \\
\text { (European Environment Agency, 2012) }\end{array}$ \\
\hline \multirow[t]{3}{*}{ General technical parameter } & \multirow[t]{3}{*}{ Production Process } & $\begin{array}{l}\text { Best Available Techniques BAT (European } \\
\text { Commission, 2014, 2017) }\end{array}$ \\
\hline & & $\begin{array}{l}\text { Environmental Profile Reports (European } \\
\text { Aluminium, 2013) }\end{array}$ \\
\hline & & $\begin{array}{l}\text { Life cycle inventory data (World } \\
\text { Aluminium, 2013) }\end{array}$ \\
\hline \multirow[t]{2}{*}{ Country specific data } & \multirow[t]{2}{*}{ Electricity Mix } & German Environment Agency (UBA, 2019a) \\
\hline & & $\begin{array}{l}\text { European Environment Agency (European } \\
\text { Environment Agency, 2018) }\end{array}$ \\
\hline Carbon Footprint & $\begin{array}{l}\text { Input material steel } \\
\text { manufacturing }\end{array}$ & ecoinvent Data Base (Ecoinvent, 2007-2013) \\
\hline
\end{tabular}

\subsubsection{Site-specific $\mathrm{CO}_{2}$ e performance modelling}

Some of the examined production sites do not have all necessary production steps for the required intermediate products located on-site. Others produce more than the locally required amounts. Hence, there exists a trading, purchase and sale of intermediate products between aluminum production sites. In a consequence, the related $\mathrm{CO}_{2} \mathrm{e}$ emissions are currently reported at the location of origin where the intermediate products are manufactured. In order to enable a comparability among manufacturing sites and a subsequent normalization to the defined functional unit ( $\mathrm{t}$ raw aluminum) in the developed model, these traded emissions are allocated by means of a credit procedure to the site where the intermediate products are finally processed to raw aluminum.

The modelling and assessment approach consists of seven calculation steps (see Figure 4). In the first three Steps (S1-S3), a combination of a bottom-up technological calculation of site-specific material flows and a top-down integration with the reported process-related $\mathrm{CO}_{2}$ emissions per site is conducted. Moreover, in Step 3 (S3) all plants are modelled as fully integrated plants and the emissions resulting from trading of intermediate products are adjusted respectively. In Step 4 (S4), the electricity consumption and its energyrelated emissions in process steps located on-site are calculated, while adjustments for traded products are 
made according to the previous steps. In Step 5 (S5) and Step 6 (S6), PFC from the anode effect (section 3.2.1) as well as upstream supply chain emissions are included. Then, in step 7 (S7) all types of previously calculated emissions are consolidated to comparable, overall site-specific values. Due to the high dependency of the developed model on the purpose of this study and the availability of data, in the following the model approach and the utilization of elementary structural data are described in a combined way.

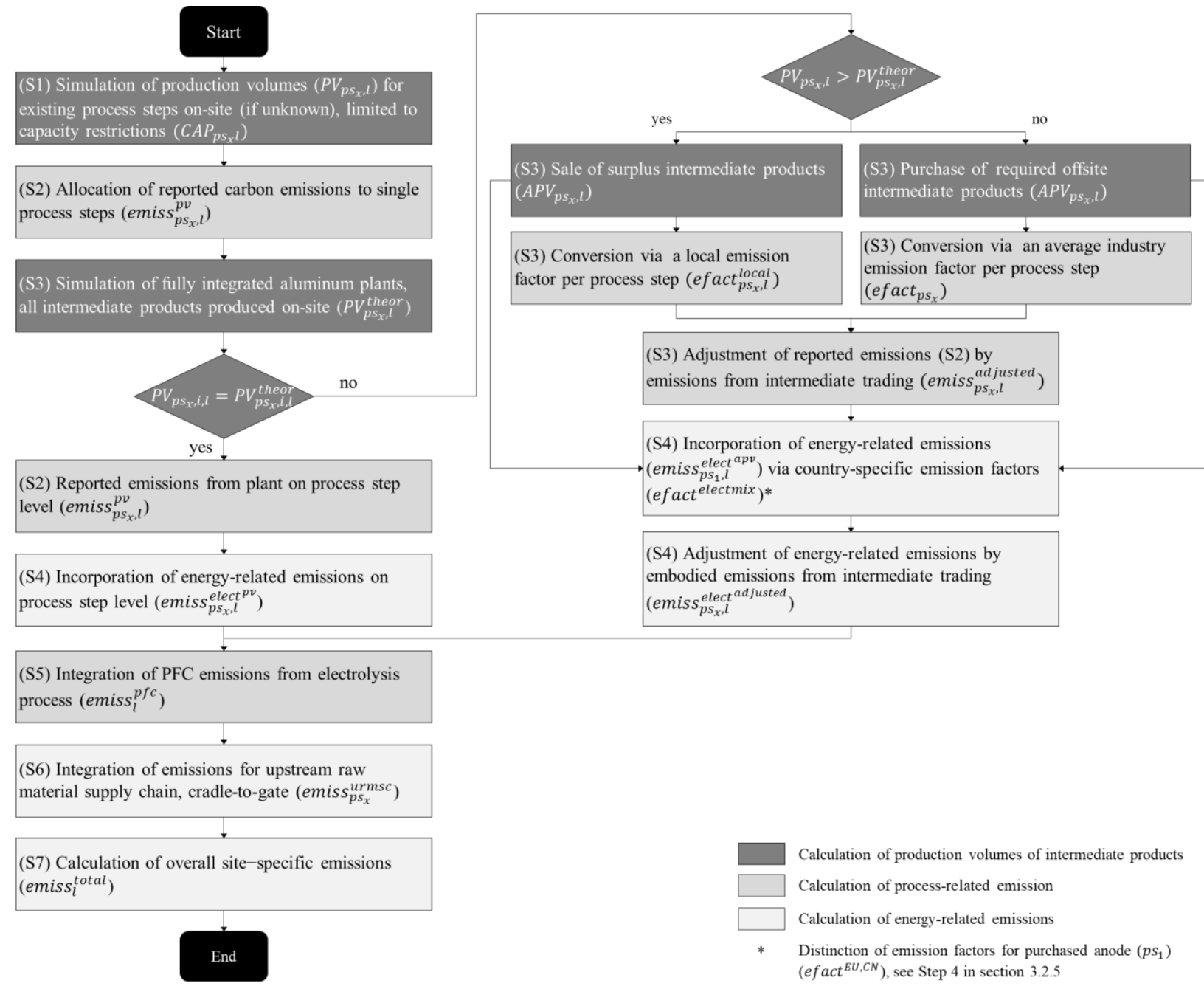

Figure 4: $\quad$ Flow chart of the site-specific $\mathrm{CO}_{2} \mathrm{e}$ approach for predefined calculation steps ${ }^{5}$

\footnotetext{
${ }^{5}$ The single steps (S1-7) correspond to section 3.2.5 and will be further explained in the text.
} 


\subsubsection{Step 1: Plant set-up to scale reported production volumes to process steps}

Initially, the plant set-up is examined at the investigated production locations $(l)$ according to the available process steps $\left(p s_{x}\right)$ on-site (see Figure 2). It serves as basis for a later determination of the trading volumes of intermediate products (section 3.2.5.3) and to derive site-specific, process-related emission factors.

In order to determine if a production process is located at the examined production site, the capacities for single process steps $\left(C A P_{p s_{x}, l}\right)$ were used (see Table A. 3, Appendix). In the aluminum industry, there exist no reporting standards for the production volumes on process step level $\left(P V_{p s_{x}, l}\right)$. Whenever the actual production volume of an upstream or downstream process onsite $\left(C A P_{p s_{x}, l}>0\right)$ is not published (see Table A. 2, Appendix), average material conversion rates $\left(m c r_{p_{x}, p s_{x}}\right)$ are consulted to estimate the production volumes, while capacity restrictions (maximum capacities per process step) are taken into account. The material conversion rates (see Table A. 1, Appendix) are aggregated European average values (in $\left[\frac{t p s_{x}}{t p s_{x}}\right]$ ), which were derived in an survey among European aluminum manufacturers (reference year 2010) by European Aluminium (2013).

As basis for the estimation, the production volume of raw aluminum $\left(P V_{p s_{3}, l}\right)$, was determined as reference value (see sections 3.2.1 and 3.2.4) and the production volumes for the upstream process steps $p s_{1}$ and $p s_{2}$ were therefore simulated backwards:

$$
\begin{aligned}
& P V_{p s_{2}, l}=\left\{\begin{array}{l}
m c r_{p s_{2}, p s_{3}} \times P V_{p s_{3}, l} \\
0
\end{array}\right. \\
& \text {, } C A P_{p s_{3}, l}>0 \\
& P V_{p s_{1}, l}=\left\{\begin{array}{l}
m c r_{p s_{1}, p s_{2}} \times P V_{p s_{2}, l} \\
0
\end{array}\right. \\
& \text {, } C A P_{p s_{3}, l}=0 \\
& \text {,CAP }{ }_{p s_{1}, l}>0 \\
& P V_{p s_{4}, l}= \begin{cases}\frac{P V_{p s_{3}, l}}{m c r_{p s_{3}, p s_{4}}} & , C A P_{p s_{4}, l}>0 \\
0 & , C A P_{p s_{4}, l}=0\end{cases}
\end{aligned}
$$

In contrast, for the downstream process in $p s_{4}$, accordingly a forward calculation was carried out. This is due to small material losses during rolling processes $\left(p s_{4}\right)$. Therefore more input of the intermediate product raw aluminum $\left(p s_{3}\right)$ is needed for one t of aluminum product (material conversion rate $>1$ ), which requires an adjustment of the calculation (see Eq. (1c)).

At this stage, due to non-availability of site-specific data, company or site-specific efficiency measures were not included. They are incorporated in the integration of top-down reported $\mathrm{CO}_{2}$ emissions per production site $^{6}$ in the following step 2 , and are further discussed in the conclusion (section 5).

\footnotetext{
${ }^{6}$ The emission reporting obligation for industrial facilities comprises various air pollutants, depending on the field of activity and predetermined threshold values. Based on the defined scope in section 3.2.2, this study focuses on the reported carbon dioxide emissions $\left(\mathrm{CO}_{2}\right)$.
} 


\subsubsection{Step 2: Allocation of reported carbon emissions to calculated carbon emissions}

Relying on the previously examined plant set-up (Step 1), the actually reported site-specific $\mathrm{CO}_{2}$ emissions of aluminum manufacturers (emiss ${ }_{l}^{\text {reported }}$ ) are integrated into the model (see Table A. 4, Appendix).

The reported site-specific $\mathrm{CO}_{2}$ emissions often comprise several emission-relevant on-site activities summarized to one overall $\mathrm{CO}_{2}$ emission value (European Environment Agency, 2012). Thus, for an assignability to the according process steps, an intermediate calculation is necessary. For this, theoretical emissions for each process step $p s$ and each location $l$ (emiss ${ }_{p s_{x}, l}^{\text {theor }}$ ) are calculated by means of industry average emission factors (efact $\left.p_{s_{x}}\right)$ (see Table A. 5, Appendix) and the actual production volumes $\left(P V_{p s_{x}, l}\right)$ defined in step 1:

emiss $_{p s_{x}, l}^{\text {theor }}=$ efact $_{p s_{x}} \times P V_{p s_{x}, l}$

Consequently, the reported emissions can be physically allocated and distributed to the respective process steps on-site ( $\tilde{x}$ serves as an auxiliary variable and corresponds to $x$ ):

emiss $_{p s_{x}, l}^{p v}=$ emiss $_{l}^{\text {reported }} \times \frac{\text { emiss }_{p s_{x}, l}^{\text {theor }}}{\sum_{\tilde{x}=1}^{4} \text { emiss }_{p s_{\tilde{x}}, l}^{\text {theor }}}$

This ensures, that the allocated emissions $\left(e m i s s_{p s_{x}, l}^{p v}\right)$ correspond to the reported emissions $\left(\right.$ emiss $_{l}^{\text {reported }}$ ) and that a plausible distribution across the process steps is performed.

In order to determine local, site-specific emission factors, consequently, the allocated emissions $\left(\operatorname{emiss}_{p s_{x}, l}^{p v}\right)$ were set in relation with the actual reported production volumes:

efact $_{p s_{x}, l}^{\text {local }}=\frac{\operatorname{emiss}_{p s_{x}, l}^{p v}}{P V_{p s_{x}, l}}$

\subsubsection{Step 3: Emission adjustment to combine the reported and calculated emissions}

In order to create a comparability among aluminum plants and to determine the trading of intermediate products between plants in an auxiliary calculation, all examined plants are simulated as fully integrated. As not all obligatory process steps for the production of raw aluminum have to be carried out on-site $\left(C A P_{p s_{x}, l}=0\right)$, all necessary intermediate products are simulated to be produced onsite (fully integrated plant). This is necessary as the reported site-specific $\mathrm{CO}_{2}$ emissions which only cover on-site activities (see Step 2) can thus report too low or too high emission values, if intermediate products are produced offsite and procured, or manufactured on-site and then sold offsite.

Similar to the auxiliary calculation in Step 1, theoretical production volumes of upstream or downstream process steps on-site are derived via average material conversion rates. At this stage, capacity constraints 
are deliberately neglected and the production volume of raw aluminum is again consulted as a reference value $\left(P V_{p s_{3}, l}^{\text {theor }}=P V_{p s_{3}, l}\right)$. The theoretical production volumes for the process steps $p s_{1}$ and $p s_{2}$ were simulated backwards, whereas for $p s_{4}$ a forward calculation was carried out (see Step 1):

$$
\begin{aligned}
& P V_{p s_{1}, l}^{\text {theor }}=m c r_{p s_{1}, p s_{2}} \times P V_{p s_{2}, l} \\
& P V_{p s_{2}, l}^{\text {theor }}=m c r_{p s_{2}, p s_{3}} \times P V_{p s_{2}, l} \\
& P V_{p s_{3}, l}^{\text {theor }}=P V_{p s_{3}, l} \\
& P V_{p s_{4}, l}^{\text {theor }}=\frac{P V_{p s_{3}, l}}{m c r_{p s_{3}, p s_{4}}}
\end{aligned}
$$

Based on Step 1, the allocated actual production volumes per location $\left(P V_{p s_{x}, l}\right)$ and the previously estimated, theoretical volumes $\left(P V_{p s_{x}, l}^{\text {theor }}\right)$ are consequently put into relation in order to define additional production volumes (surpluses or shortages):

$$
A P V_{p s_{x}, l}=P V_{p s_{x}, l}-P V_{p s_{x}, l}^{\text {theor }}
$$

In case the location's production volume is lower than the required theoretical production volume (negative $A P V_{p s_{x}, l}$, a purchase of intermediate products from another site is assumed. Vice versa, if the volume of the actual production on-site exceeds the necessary amount for the following process step, it indicates an offsite sale (positive $A P V_{p s_{x}, l}$ ).

The embodied emissions which come along with the trading of intermediate products (emiss ${ }_{p s_{x}, l}^{a p v}$, were defined by emission factors $e$ fact ${ }_{p s_{x}}$. As for purchased products the origin of production cannot be traced back, average European factors were applied $\left(\right.$ efact $_{p s_{x}}$, see Table A. 5, Appendix). In contrast, for sold products the derived local emission factors $\left(e f a c t_{p s_{x}, l}^{l o c a l}\right)$ were consulted (see Step 2):

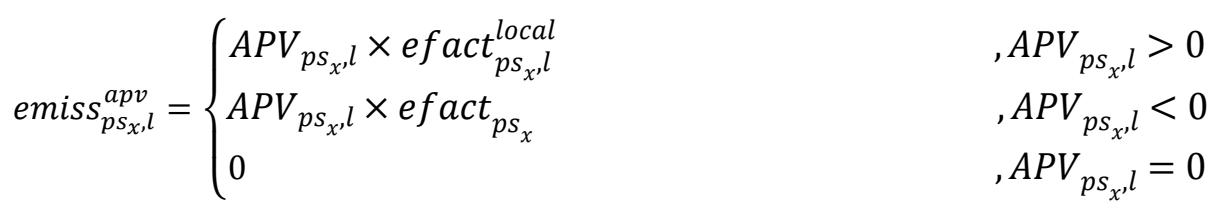

To create a comparability among aluminum production sites, the allocated and reported $\mathrm{CO}_{2}$ emissions (see Step 2) are adjusted by the emissions resulting from traded intermediate products (additional production volumes):

emiss $_{p s_{x}, l}^{\text {adjusted }}=$ emiss $_{p s_{x}, l}^{p v}+\operatorname{emiss}_{p s_{x}, l}^{a p v}$

With regard to the defined functional unit of $\mathrm{kgCO}_{2} \mathrm{e} / \mathrm{t}$ raw aluminum (see section 3.2.2), the values were conclusively normalized to the amount of raw aluminum produced onsite $\left(P V_{p_{S_{3}}, l}\right)$. 


\subsubsection{Step 4: Electricity consumption for produced and traded products}

The production process of primary aluminum is highly energy intensive and particularly requires electricity (see section1). As no site-specific information on the electricity consumption is available, a calculation on a national basis was carried out. Therefore, at first the amount of electricity according to the actual production volumes of intermediate products $\left(P V_{p s_{x}, l}\right)$ is calculated by means of average input factors (see Table A. 6, Appendix) for the energy amount required per process step $\left(i p_{p s_{x}, l}^{\text {elect }}\right)$ :

$\operatorname{elect}_{p s_{x}, l}^{p v}=P V_{p s_{x}, l} \times i p_{p s_{x}, l}^{\text {elect }}$

It is assumed that the production sites rely on the electricity provided by national power grids. Thus the country-specific energy mix and country-specific conversion rates of the energy mix to $\mathrm{CO}_{2} \mathrm{e}$

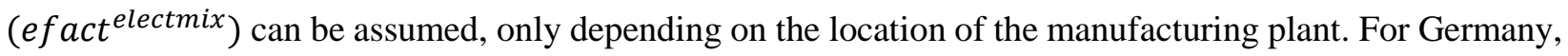
this accounts to $0.573 \mathrm{kgCO}_{2} \mathrm{e} / \mathrm{kWh}$ (UBA, 2019b) via the following equation:

$\operatorname{emiss}_{p s_{x}, l}^{\text {elect }}{ }^{p v}=\operatorname{elect}_{p s_{x}, l}^{P V} \times$ efact $^{\text {electmix }}$

Similar to Step 3, the emissions related to the traded intermediate products $\left(A P V_{p s_{x}, l}\right)$ are determined for each location $l$ for process steps $p s_{2}$ to $p s_{4}$ (equation (7)). It is assumed that trading is conducted exclusively within country borders and thus the same emission factor ( fact $^{\text {electmix }}$ ) applies to all traded products.

In terms of trading of the intermediate product anode, a distinction is made between sold $\left(A P V_{p s_{x}, l}>0\right)$ and purchased additional production volume $\left(A P V_{p s_{x}, l}<0\right)$ :

emiss $_{p s_{1}, l}^{\text {elect }}$ apv $= \begin{cases}A P V_{p s_{1}, l} \times i p_{p s_{1}, l}^{\text {elect }} \times \text { efact }^{\text {electmix }} & , A P V_{p s_{1}, l}>0 \\ A P V_{p s_{1}, l} \times i p_{p s_{1}, l}^{\text {elect }} \times \text { efact }^{E U, C N} & , A P V_{p s_{1}, l}<0 \\ 0 & , A P V_{p s_{1}, l}=0\end{cases}$

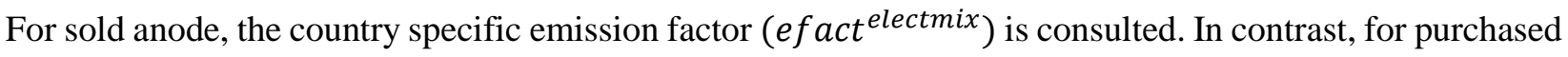
anode the mean value of the European and Chinese emission factor for electricity production (efact ${ }^{E U, C N}$ ) derived from Ecoinvent (2007-2013) is assumed with $0.818 \mathrm{kgCO}_{2} \mathrm{e} / \mathrm{kWh}\left(\mathrm{EU}: 0.488 \mathrm{kgCO}_{2} \mathrm{e} / \mathrm{kWh}, \mathrm{CN}\right.$ : $1.148 \mathrm{kgCO}_{2} \mathrm{e} / \mathrm{kWh}$ ). This assumption is based on the fact that no exact country of origin is published for anode products. But, according to Norsk Hydro ASA (2012) and TRIMET Aluminium SE (2013) the examined sites rely primarily on anodes sourced from Europe and China.

Similar to the emission adjustment for the process-related emissions in Step 3, the energy-related, embodied emissions from the local on-site electricity consumption are combined with the embodied emissions caused from electricity used to produce the traded intermediate products:

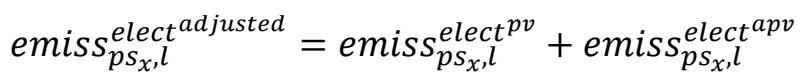


A normalization to the functional unit is conducted, similar to Step 3.

\subsubsection{Step 5: PFC emissions from electrolysis process}

Besides the process- and energy related emissions $\left(\mathrm{CO}_{2}\right.$ and other $\mathrm{GHG}$ emissions described in $\left.\mathrm{CO}_{2} \mathrm{e}\right)$ which were considered in the calculation so far, perfluorocarbon emissions $\left(\mathrm{CF}_{4}\right.$ and $\left.\mathrm{C}_{2} \mathrm{~F}_{6}\right)$ are incorporated in the assessment (see section 3.2.2). PFC emissions are part of the European reporting obligation for non-ferrous metal producing plants (E-PRTR). Facilities are required to report the total annual amount of perfluorocarbon emissions without a further breakdown into the type or exact composition (see Table A. 4, Appendix). Hence, the reported PFC emissions per production site $\left(\right.$ emiss $_{l}^{\text {reported }}{ }^{p f c}$ ) were first converted into their GWP (expressed in $\mathrm{CO}_{2} \mathrm{e}$ ) by means of a characterization coefficient (emission factor (efact $\varnothing_{\varnothing}^{p f c}$ )). Then, a normalization to the functional unit was conducted:

emiss $_{l}^{\text {pfc }}=\frac{\text { emiss }_{l}^{\text {reported }}{ }^{p f c} \times 1000 \times \text { efact }_{\emptyset}^{p f c}}{P V_{p s_{3}, l}}$

As the exact composition of different PFC molecules per site is not available, an average ratio for Centre Worked Prebake - Point centre feed anodes (PFPB) is applied in combination with the GWP of $\mathrm{CF}_{4}$ and $\mathrm{C}_{2} \mathrm{~F}_{6}$ (World Aluminium, 2016).

efact $_{\varnothing}^{p f c}=\left(\frac{9}{10} \times 7,390\right)+\left(\frac{1}{10} \times 12,200\right)$

\subsubsection{Step 6: Upstream cradle-to-gate supply chain emissions}

In order to fully assess the defined scope and the system boundaries (cradle-to-gate) (see sections 3.2.2 and 3.2.3), finally emissions from the upstream raw material supply chain were integrated. As respective sitespecific information is not publically available, industry average values from the ecoinvent database (Ecoinvent, 2007-2013) were consulted.

Due to the site-specific consideration of the emissions from the anode production (emiss ${ }_{p s_{1}, l}^{\text {adjusted }}$ ), the emissions for electricity consumption for all process steps (emiss $\left.p_{p s_{x}, l}^{\text {elect }}{ }^{\text {adjusted }}\right)$ and the reported PFC emissions $\left(\right.$ emiss $_{l}^{\text {reported }}{ }^{p f c}$ ), these values have accordingly been excluded from the industry averages. As all examined manufacturers are located in the same country, consequently the same value of $2,814 \mathrm{kgCO}_{2} \mathrm{e}$ / t raw aluminum (Ecoinvent, 2007-2013) for upstream raw material supply chain activities (emiss ${ }_{l}^{\text {urmsc }}$ ) applies. 


\subsubsection{Step 7: Overall site-specific adjusted emissions}

Finally, the total amount of site-specific emissions per production location can be derived by the addition

of the previously calculated, different types of emissions (process-related emissions emiss ${ }_{p s_{x}, l}^{\text {adjusted }}$ and energy-related emissions emiss elect $_{s_{x}, l}^{\text {adjusted }}$, PFC emissions emiss $_{l}^{p f c}$ and upstream supply chain emissions

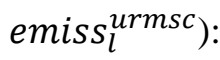

emiss $_{l}^{\text {total }}=\sum_{x=1}^{4}$ emiss $_{p s_{x}, l}^{\text {adjusted }}+\sum_{x=1}^{4}$ emiss $_{p s_{x}, l}^{\text {elect }}{ }^{\text {adjusted }}+$ emiss $_{l}^{\text {pfc }}+$ emiss $_{l}^{\text {urmsc }}$

With this value, the environmental performance of different aluminum manufacturing sites provides the basis for a possible integration into supplier selection decisions (see section 4.3).

\section{Application of the site-specific $\mathrm{CO}_{2}$ e assessment model on automotive case study}

\subsection{Results of the site-specific $\mathrm{CO}_{2} \mathrm{e}$ model applied on German aluminum manufacturers}

According to the defined scope (see section 3.2.2), the developed model was applied to all four electrolysisbased primary aluminum manufacturing sites in Germany which have a maximum of four process steps $\left(p s_{x}\right)$ at location $(l)\left(p s_{x, l}, x \in\{1 ; 4\}, l \in\{1 ; 4\}\right)$. The four German sites are located in predominately West and Northern Germany (see Figure 3) and produced a total of 0.410 thousand metric tons of primary aluminum in 2012. They account for approximately $39 \%$ of the total aluminum production in Germany. The reminder is covered by secondary aluminum production.

The estimated results for the production sites under study (total emissions per production site and functional unit) range from the most efficient, "Best-in-Class" $(\mathrm{BiC})$ plant $13,689 \mathrm{kgCO}_{2} \mathrm{e} / \mathrm{t}$ raw aluminum to the least efficient "Worst-in-Class" (WiC) plant 14,946 $\mathrm{kgCO}_{2} \mathrm{e} / \mathrm{t}$ raw aluminum. As shown in Figure 5, the results have a range of approximately $9 \%$. On average, $14,111 \mathrm{kgCO}_{2} \mathrm{e} / \mathrm{t}$ raw aluminum are emitted among the four examined primary aluminum plants in Germany.

Despite the relatively low percentage deviation between the $\mathrm{BiC}$ and $\mathrm{WiC}$ sites, the absolute difference of $1,275 \mathrm{kgCO}_{2} \mathrm{e} / \mathrm{t}$ raw aluminum (see Figure 5), shows the need for a $\mathrm{CO}_{2} \mathrm{e}$ performance assessment of suppliers on site level to be used in supplier selection and purchase decision making.

The deviations of the environmental performances of the examined manufacturing sites, can mainly be explained by differences in company-internal process know-how and specific efficiency measures per process step respectively advanced technological installations. However, due to the top-down integration approach of the reported $\mathrm{CO}_{2}$ emissions, which is related to the main production volumes, already implemented company-specific process expertise is incorporated in the model. The applied allocation 
procedure on process step level (see Step 2, section 3.2.5.2), can lead to slight discrepancies in terms of the single values per process step.

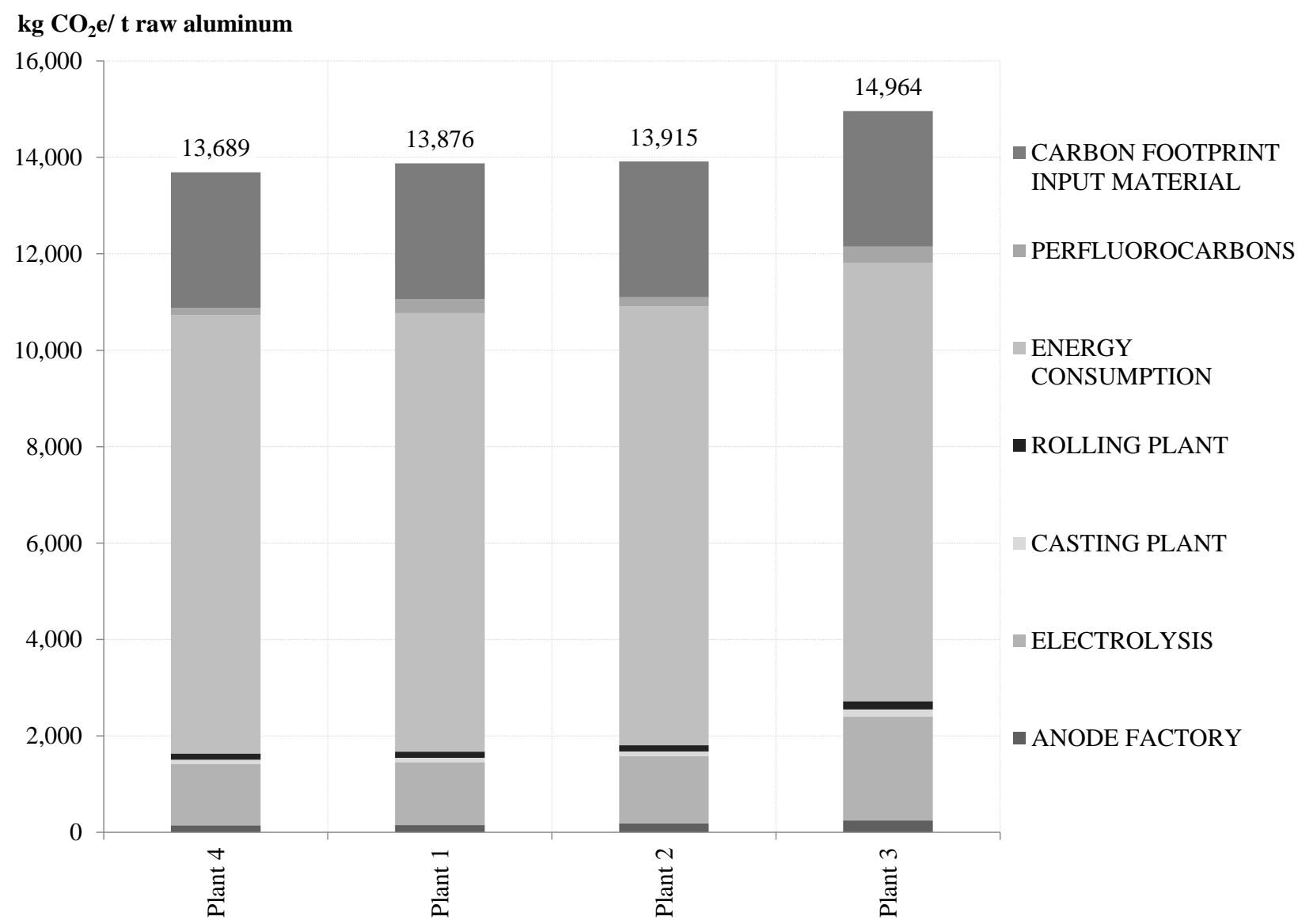

Figure 5: $\quad$ Results of the four examined German primary aluminum plants after the emission adjustment)

In order to derive consequences on an European emission level, the results from the developed site-specific, attributional approach were used in an exemplary application in the automotive sector. For this, the average material composition of the VW GOLF VII (Lieberwirth and Krampitz, 2015; Schmid and Zur-Lage, 2014), the bestselling car in the European automotive market in 2017, is used with a share of $119 \mathrm{~kg}$ aluminum ( $8.1 \%$ of the entire vehicle weight) as basis for the calculation. Combining the estimated average amount of $14,111 \mathrm{kgCO}_{2} \mathrm{e} / \mathrm{t}$ raw aluminum with a projection on all annually newly registered 15.1 mio. passenger cars in Europe in 2017 (European Commission, 2019a) result in $4.629 \mathrm{Mt} \mathrm{CO}_{2} \mathrm{e}$ which constitutes a share of $0.6 \%$ of the total annual GHG emissions in Europe (European Environment Agency, 2019b).

Using the same parameters in combination with the $\mathrm{BiC}$ and $\mathrm{WiC}$ aluminum manufacturers, a possible reduction potential of $2.3 \mathrm{Mt} \mathrm{CO}_{2} \mathrm{e}$ annually is revealed with respect to all new vehicle registrations in Europe in 2017. Again, this demonstrates the relevance of site-specific performance evaluations and the 
need to extend technological efficiency measures in the raw aluminum production. Due to capacity restrictions, the access to material from the $\mathrm{BiC}$ aluminum manufacturing site for all customers is limited and thus, only an individual corporate decision maker's perspective is portrayed.

Nevertheless, a growing trend towards and demand for transparency in value chains and green, climatefriendly products as well as environmentally-sustainable production, will force raw material producers to rethink and adjust production processes in order to maintain competitive advantages. In a consequence, it can trigger a change in the aluminum producing sector and aluminum trading market with respect to reducing the carbon footprint of aluminum products in general. Against the background of corporate carbonneutrality projects such as the Volkswagen ID project, even BiC producers will be urged to further optimize the efficiency of their production processes and reduce GHG and other emissions and environmental impacts to a minimum.

\subsection{Validation of the $\mathrm{CO}_{2} \mathrm{e}$ assessment model}

The calculation procedure of the developed model (single steps of the calculation) including the described logic for comparability by the simulation of fully integrated sits (see Step 3), as well as the made assumptions were continuously analyzed and validated with one German manufacturer in in-depth expert interviews over a period of two years. The detailed modelling approach was confirmed, but no internal know-how was revealed. Only percentage variances of the absolute values can be published because of a non-disclosure agreement. The model showed a very promising percentage variation from the absolute value of max. $6 \%$.

In addition, the estimated average value was compared to the European average value of $12,121 \mathrm{kgCO}_{2} \mathrm{e} / \mathrm{t}$ raw aluminum derived from the ecoinvent data base (Ecoinvent, 2007-2013). This value relies on an average electricity generation emission intensity of $0.353 \mathrm{kgCO}_{2} \mathrm{e} / \mathrm{kWh}$ for Europe in 2012 (European Environment Agency, 2018). Furthermore, the significant difference of $1,990 \mathrm{kgCO}_{2} \mathrm{e} / \mathrm{t}$ raw aluminum points out the crucial role of electricity - especially for the high amount of electricity required for electrolytic reduction process and the underlying national energy mix depending on the sites' location. Due to the defined scope of the study, the model uses the emission intensity for the German energy mix in 2012 of $0.573 \mathrm{kgCO}_{2} \mathrm{e} /$ $\mathrm{kWh}$ (UBA, 2019b), illustrating a deviation of $62 \%\left(0.220 \mathrm{kgCO}_{2} \mathrm{e} / \mathrm{kWh}\right)$ compared to the European average. Moreover, the total average amount for PFC emissions of $1,860 \mathrm{kgCO}_{2} \mathrm{e} / \mathrm{t}$ raw aluminum for Europe in the ecoinvent database exceeds the reported and normalized PFC emissions in the model on average by $1,559 \mathrm{kgCO}_{2} \mathrm{e} / \mathrm{t}$ raw aluminum (83.8\%). This can be considered as indication for the efficient process control and conduction of the examined production sites.

A manual manipulation of the ecoinvent data with the German emission intensity and the inclusion of the average PFC emissions from the developed model, results in an adjusted average value of $13,921 \mathrm{kgCO}_{2} \mathrm{e} /$ 
$\mathrm{t}$ raw aluminum. Thus, only a slight deviation of $1.37 \%\left(190 \mathrm{kgCO}_{2} \mathrm{e} / \mathrm{t}\right.$ raw aluminum) in comparison to the average estimated value of $14,111 \mathrm{kgCO}_{2} \mathrm{e} / \mathrm{t}$ raw aluminum of the four considered sites becomes apparent.

\subsection{Exemplary application of site-specific $\mathrm{CO}_{2} \mathrm{e}$ emissions in a decision support model}

In order to demonstrate the effects of an integration of $\mathrm{CO}_{2} \mathrm{e}$ as additional criteria on procurement decisionmaking, the integrated $\mathrm{CO}_{2} \mathrm{e}$ assessment and decision support model developed by Schiessl et al. (2020) is consulted. In a multi-criteria decision analysis approach Schiessl et al. (2020) combined an analytical hierarchy process (AHP) and the technique for order preference by similarity to ideal solution (TOPSIS) (see Figure 1). After a selection of decision criteria based on a literature review and expert consultation, purchasing experts from a German original equipment manufacturer (OEM) were interviewed face-to-face and criteria preferences and respective weightings were derived by means of pairwise comparisons. The TOPSIS method was then used for a Tier-1 supplier ranking, according to the selected decision criteria and the respective real-world supplier performance data for a chosen mechanical component case based on aluminum with a weight of $5.7 \mathrm{~kg}$. For more in-depth information about the approach (development, data, application and sensitivity analysis) reference is made to Schiessl et al. (2020).

In an exemplary application, the estimated $\mathrm{CO}_{2} \mathrm{e}$ performance data for aluminum suppliers (see Figure 5) are integrated, in relation to the sample part weight, in the described decision support model. Therefore, the consolidated AHP results of the selected sample of 25 purchasing experts from the non-consumable division (see Table 3) based on Schiessl et al. (2020) are consulted as basis for a supplier selection. The TOPSIS model is equally applied for the ranking of suppliers according to their site- and product-specific environmental performances in combination with the derived AHP criteria weights from the expert interviews (see Table 3). In this case study, a German automobile manufacturer selects a supplier for a new sample part made from aluminum with a weight of $5.7 \mathrm{~kg}$ (see Table 4). ${ }^{7}$

\footnotetext{
${ }^{7}$ The sample part used can be found in the powertrain of every Internal Combustion Engine Vehicle (ICEV) only varying in size depending on the performance spectrum of the engine and the general vehicle dimension. Due to confidentiality reasons no further information can be provided.
} 
Table 3: $\quad$ Chosen main and sub-criteria in the problem hierarchy incl. consolidated global criteria weights

\begin{tabular}{|c|c|c|c|c|c|c|c|c|c|}
\hline \multirow{3}{*}{ Main criteria } & \multicolumn{2}{|l|}{$\mathrm{C} 1$} & \multicolumn{2}{|l|}{$\mathrm{C} 2$} & \multicolumn{2}{|l|}{$\mathrm{C} 3$} & \multicolumn{2}{|l|}{$\mathrm{C} 4$} & \multirow{2}{*}{$\begin{array}{l}\text { C5 } \\
\text { Environmental } \\
\text { sustainability }\end{array}$} \\
\hline & \multicolumn{2}{|l|}{ Cost } & \multicolumn{2}{|l|}{ Quality \& production } & \multicolumn{2}{|l|}{ Flexibility } & \multicolumn{2}{|c|}{$\begin{array}{l}\text { Development \& } \\
\text { innovation }\end{array}$} & \\
\hline & $\mathrm{C} 11$ & $\mathrm{C} 12$ & $\mathrm{C} 21$ & $\mathrm{C} 22$ & C31 & $\mathrm{C} 32$ & $\mathrm{C} 41$ & $\mathrm{C} 42$ & $\mathrm{C} 51$ \\
\hline Sub-criteria & Parts cost & $\begin{array}{l}\text { Industriali- } \\
\text { zation } \\
\text { Cost }\end{array}$ & $\begin{array}{l}\text { Machine conditions } \\
\text { and manufacturing } \\
\text { technology }\end{array}$ & $\begin{array}{l}\text { Testing } \\
\text { processes } \\
\text { and } \\
\text { facilities }\end{array}$ & $\begin{array}{l}\text { Product } \\
\text { development/ } \\
\text { industrialization } \\
\text { time }\end{array}$ & $\begin{array}{l}\text { Infrastructure } \\
\text { and supply }\end{array}$ & $\begin{array}{l}\text { Developmen } \\
\text { t experience }\end{array}$ & $\begin{array}{l}\text { Investment } \\
\text { in } \\
\text { innovation }\end{array}$ & $\begin{array}{l}\mathrm{CO}_{2} \mathrm{e} \text { component } \\
\text { manufacturing }\end{array}$ \\
\hline $\min$ & $1.98 \%$ & $1.39 \%$ & $3.39 \%$ & $2.37 \%$ & $1.31 \%$ & $1.96 \%$ & $2.25 \%$ & $1.49 \%$ & $2.44 \%$ \\
\hline $\max$ & $44.16 \%$ & $25.05 \%$ & $37.59 \%$ & $38.62 \%$ & $25.51 \%$ & $42.16 \%$ & $23.43 \%$ & $33.19 \%$ & $2.66 \%$ \\
\hline $\begin{array}{l}\text { geometric } \\
\text { mean (AIJ) }\end{array}$ & $20.89 \%$ & $9.98 \%$ & $16.33 \%$ & $11.45 \%$ & $5.68 \%$ & $12.71 \%$ & $13.14 \%$ & $7.15 \%$ & $2.67 \%$ \\
\hline
\end{tabular}




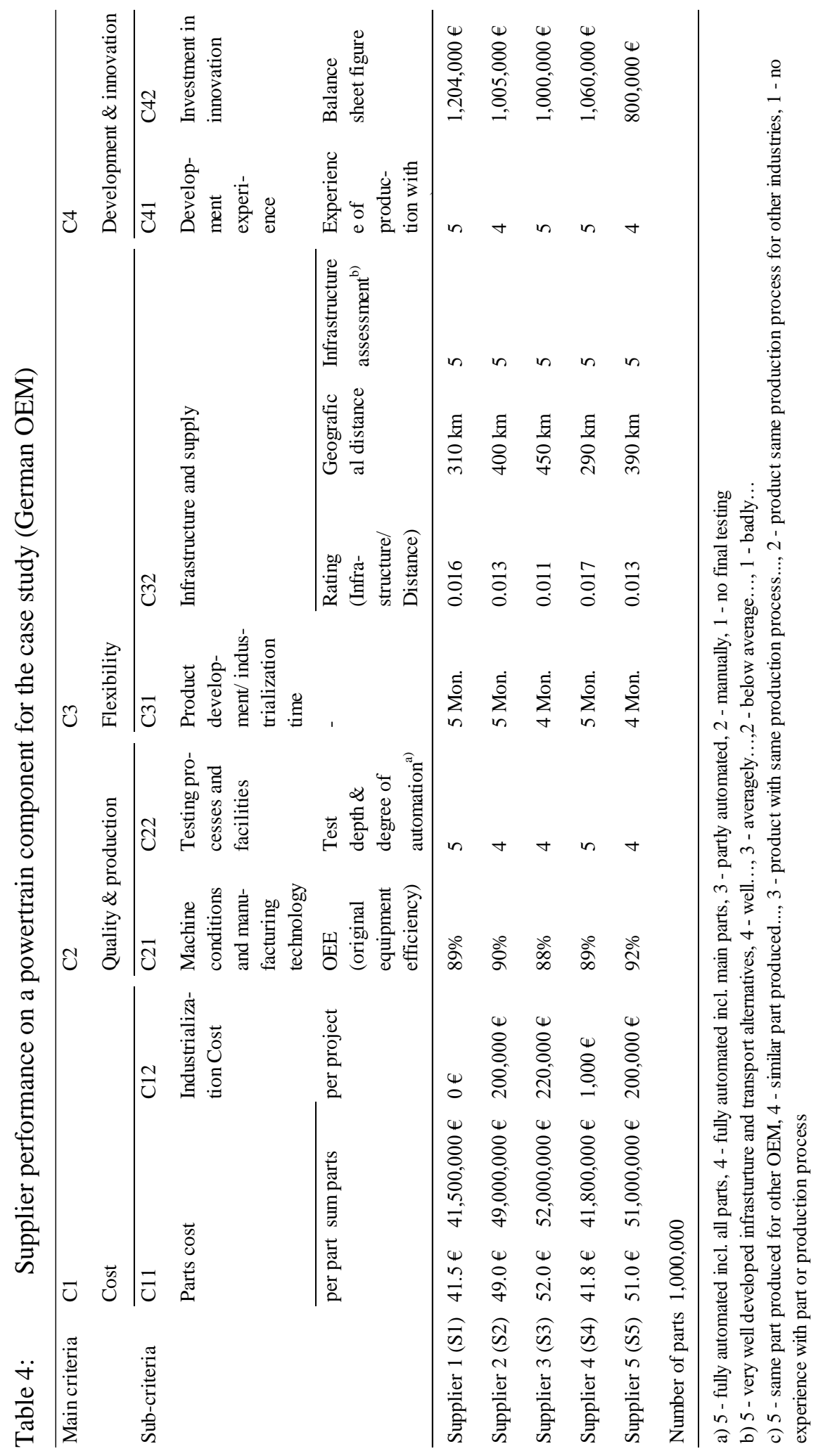


In scientific publications, only data on regional industry averages for some selected countries or site-specific data for a few selected plants can be found (see section 2). Thus, the available data is restricted to LCA databases which rely on industry averages on a regional European level (RER). Therefore, the manipulated average cradle-to-gate value including emissions from all upstream activities of $13,921 \mathrm{kgCO}_{2} \mathrm{e} / \mathrm{t}$ raw aluminum (Ecoinvent, 2007-2013) (see section 4.2), is applied to the sample part and respectively shows an environmental performance score of $79.350 \mathrm{~kg} \mathrm{CO}_{2} / \mathrm{t}$ raw aluminum ${ }^{8}$ that is equal for all five considered suppliers (see Figure 6, Case 1). Taking into account the environmental performance data in combination with the performance of the remaining criteria, the application of the combined AHP/TOPSIS model shows the following ranking of suppliers: $\mathrm{S} 1 \rightarrow \mathrm{S} 4 \rightarrow \mathrm{S} 3 \rightarrow \mathrm{S} 2 \rightarrow \mathrm{S} 5$ (see Table 5 and Figure 6).

Now, the results of the site-specific $\mathrm{CO}_{2} \mathrm{e}$ assessment model for aluminum developed in section 3.2 (see Figure 5) are applied to the same sample part (5.7 kg aluminum) and integrated in the supplier selection model to derive a ranking of suppliers. Due to the now consulted site-specific values per ton raw aluminum the $\mathrm{CO}_{2} \mathrm{e}$ performance of the suppliers vary (see Figure 6, Case 2). The supplier and site-specific values of the four German primary aluminum plants lead to a total $\mathrm{CO}_{2} \mathrm{e}$ performance of $85.29 \mathrm{~kg} \mathrm{CO}_{2} \mathrm{e} /$ part for supplier 1 (by 14,964 $\mathrm{kg} \mathrm{CO}_{2} \mathrm{e} / \mathrm{t}$ raw aluminum), of $79.09 \mathrm{~kg} \mathrm{CO}_{2} \mathrm{e} /$ part for supplier 2 (by 13,876 $\mathrm{kg} \mathrm{CO}_{2} \mathrm{e} /$ $\mathrm{t}$ raw aluminum), of $79.09 \mathrm{~kg} \mathrm{CO}_{2} \mathrm{e} /$ part for supplier 3 (by $13,876 \mathrm{~kg} \mathrm{CO}_{2} \mathrm{e} / \mathrm{t}$ raw aluminum) ${ }^{9}$, of $78.03 \mathrm{~kg}$ $\mathrm{CO}_{2} \mathrm{e} /$ part for supplier 4 (by 13,689 $\mathrm{kg} \mathrm{CO}_{2} \mathrm{e} / \mathrm{t}$ raw aluminum) and of $79.32 \mathrm{~kg} \mathrm{CO}_{2} \mathrm{e} /$ part for supplier 5 (by $13,915 \mathrm{~kg} \mathrm{CO} 2 \mathrm{e} / \mathrm{t}$ raw aluminum). Based on the investigated criteria weight of $2.67 \%$ for the new environmental decision criteria (C51) in relation to other criteria (such as cost, C1 30.87\% and quality, C2 27.78) from Schiessl et al. (2020) (see Table 3), the application of the estimated site-specific supplier performance scores, lead to a new supplier ranking: $\mathrm{S} 4 \rightarrow \mathrm{S} 1 \rightarrow \mathrm{S} 3 \rightarrow \mathrm{S} 2 \rightarrow \mathrm{S} 5$ (see Table 6 and Figure 6).

Table 5: $\quad$ Evaluation and ranking of alternatives (Case 1) based on average emissions (RER)

\begin{tabular}{lllll}
\hline Supplier & $\begin{array}{l}\text { Distance } \\
(P I S)\end{array}$ & $\begin{array}{l}\text { Distance } \\
(N I S)\end{array}$ & $\begin{array}{l}\text { Proximity Index } \\
\text { (relative closeness) }\end{array}$ & Ranking \\
\cline { 2 - 4 } & $d s^{+}$ & $d s^{-}$ & $P_{i}=\frac{d s^{-}}{d s^{+}+d s^{-}}$ & \\
\hline S1 & 0.007 & 0.0711 & 0.905 & 1 \\
S2 & 0.064 & 0.0119 & 0.157 & 4 \\
S3 & 0.071 & 0.0152 & 0.177 & 3 \\
S4 & 0.008 & 0.0714 & 0.904 & 2 \\
S5 & 0.065 & 0.0111 & 0.146 & 5 \\
\hline
\end{tabular}

Table 6. Evaluation and ranking of alternatives (Case 2) based on $\mathrm{ECCO}_{2}$ calculation - Aluminum

\begin{tabular}{lllll}
\hline Supplier & $\begin{array}{l}\text { Distance } \\
(P I S)\end{array}$ & $\begin{array}{l}\text { Distance } \\
(N I S)\end{array}$ & $\begin{array}{l}\text { Proximity Index } \\
\text { (relative closeness) }\end{array}$ & Ranking \\
\cline { 2 - 4 } & $d s^{+}$ & $d s^{-}$ & $P_{i}=\frac{d s^{-}}{d s^{+}+d s^{-}}$ & \\
\hline S1 & 0.008 & 0.0711 & 0.904 & 2 \\
S2 & 0.064 & 0.0119 & 0.158 & 4 \\
S3 & 0.071 & 0.0152 & 0.177 & 3 \\
S4 & 0.008 & 0.0714 & 0.905 & 1 \\
S5 & 0.065 & 0.0111 & 0.146 & 5 \\
\hline
\end{tabular}

\footnotetext{
${ }^{8}$ The study focuses on the emissions from raw material production exclusively and does not consider the emissions for further processing or transport from the considered Tier-1 supplier.

${ }^{9}$ One site-specific environmental performance value of an aluminum production site is used twice, as different Tier1 suppliers source their raw material, in this case aluminum, from the same Tier-2 sub-supplier, respectively raw material manufacturer for aluminum (see Figure 5).
} 
The illustrated deviation of $9.31 \%\left(7.27 \mathrm{~kg} \mathrm{CO}_{2} \mathrm{e} /\right.$ part) of the environmental performance scores of supplier 1 and 4 (Case 2), resulting from the different environmental efficiencies of the underlying aluminum production sites, leads to a different supplier ranking, preferring supplier 4 over supplier 1 . Thus, the assessment of suppliers' $\mathrm{CO}_{2}$ e performances on a site-specific level and the integration as decision criteria for supplier selections can change decision making.

Prior to the integration of the site-specific $\mathrm{CO}_{2} \mathrm{e}$ performances, the overall project cost (1 Mio parts, see Table 4) of the preferred supplier S1 is 41.50 Mio $€$ and it is corresponding to emissions of 85,294 t $\mathrm{CO}_{2} \mathrm{e}$ during the entire project duration. Supplier S4 has overall project cost of 41.80 Mio $€$ while emitting 78,028

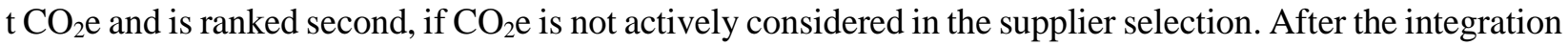
of $\mathrm{CO}_{2} \mathrm{e}$ as additional selection criteria and the criteria weighting according to Schiessl et al. (2020), supplier S4 now represents due to better environmental performance the preferred supplier, with additional project cost of only 0.30 Mio $€$ while emitting 7,265 t $\mathrm{CO}_{2} \mathrm{e}$ less than supplier S1. Moreover, this corresponds to a $\mathrm{CO}_{2} \mathrm{e}$ reduction price of $39.34 € / \mathrm{tCO}_{2} \mathrm{e}$ and shows, that national carbon prices, for example $25 € / \mathrm{tCO}_{2} \mathrm{e}$ from the German national emissions trading system (nEHS) for the traffic and building sector (The Federal Government, 2019), would currently be too low and would thus not be relevant for supplier decisions.

This example illustrates, that the integration of site-specific performances in supplier selection decisions also allows for a simultaneous consideration of economic and environmental effects. It thus enables the simulation of future scenarios in order to formulate the specification of new selection criteria (here $\left.\mathrm{CO}_{2} \mathrm{e}\right)$ and to derive new sustainable supplier selection strategies.

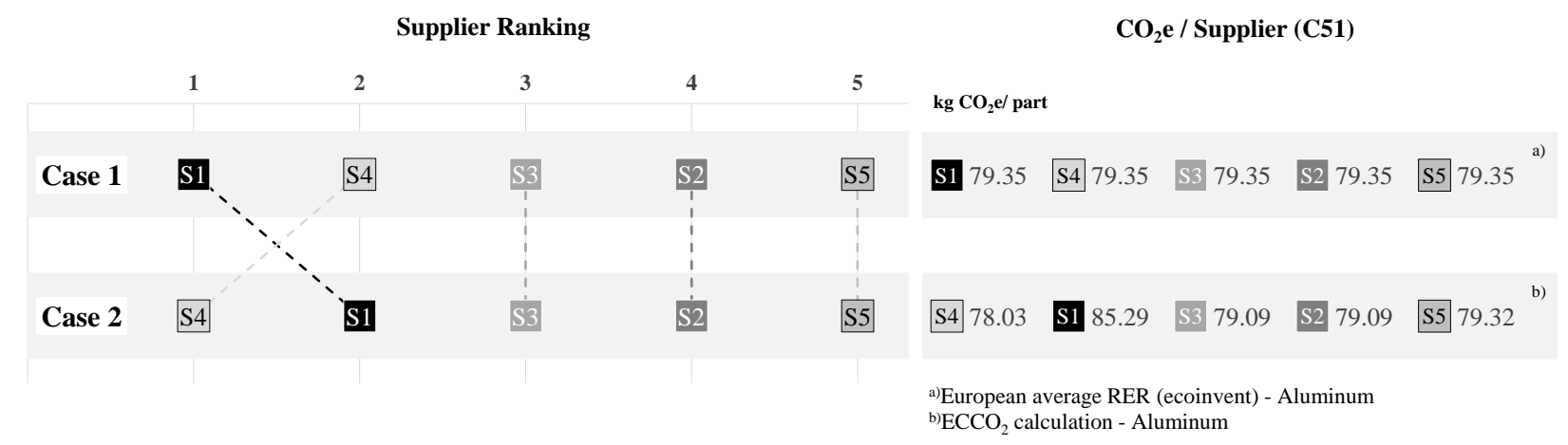

Figure 6: $\quad$ Supplier-specific $\mathrm{CO}_{2}$ e emissions per sample aluminum production and the influence of $\mathrm{CO}_{2} \mathrm{e}(\mathrm{C} 51)$ on supplier ranking

\section{Conclusion and outlook}

In line with the overarching goal of limiting global warming, diverse research fields gain greatly in importance. The production of raw aluminum and aluminum parts that are used for manufacturing passenger 
vehicles of the mobility sector illustrates only one out of many areas in which knowledgeable supplier selection can make a significant contribution to the reduction of environmental impact.

However, to evaluate and integrate the environmental performance of raw material manufacturers on production site level into a decision making process, primary data is not yet sufficiently available. Particularly, the use of average industry data does not serve the intended purpose and does not enable a comparability among suppliers. The developed approach overcomes these limitations by extending the scope of the classical, bottom-up process LCA method by means of a top-down incorporation of reported company-specific emissions from official reporting to EU authorities. In this study, the suggested procedure assures that company-specific as well as site-specific internal process know-how is included despite an unavailability of explicit data (see Step 3 in section 3.2.5) and that the complexity in terms of process depth is limited to a required minimum. In a cradle-to-gate assessment, the developed model was applied in a case study on aluminum manufacturing in Germany, showing variations of $8.4 \%$ between plants from the most efficient $\mathrm{BiC}$ plant $13,689 \mathrm{kgCO}_{2} \mathrm{e} / \mathrm{t}$ raw aluminum to the least efficient $\mathrm{WiC}$ plant $14,946 \mathrm{kgCO}_{2} \mathrm{e} / \mathrm{t}$ raw aluminum.

However, the developed approach shows some limitations which could be considered and investigated in future research. Regarding the unpublished production volumes of production sites, such as the upstream process steps conducted in the anode factory or the electrolysis, a backwards calculation was carried out using the downstream process step of raw aluminum production as reference value (see section 3.2.5, Step 1). Some aluminum manufacturers could intentionally produce more anode or molten aluminum than required for the locally produced raw aluminum specifically for market sale. If this data could be collected e.g. by expert interviews or field studies or official numbers from producers, this 'backward calculation' could be replaced by actual data, which is not available at present. In addition, based on the goal to create a comparability among aluminum manufacturers, customer specific alloying, which is highly common for example in the automotive industry, was neglected. However, this information could be integrated into the model according to the emissions from upstream supply chain activities derived from an LCA database or even on a more specific level, if available. The creation of a site-specific upstream supply chain transparency of the input material for the raw material production is an interesting area for future research and an opportunity to increase the GHG emission accuracy over the whole supply chain. Future studies should examine the currently excluded emissions for further processing and transport which would contribute to a higher supply chain transparency. Moreover, an extension of the geographic scope to an international level seems promising in order to create transparency for global supply chains and to identify eventual GHG emission shifting. The results of the case study could also be applied for supplier selection decisions in other industries such as for example the construction, packaging or engineering industry. 
In summary, from a scientific point of view, the proposed site-specific assessment approach creates a higher level of transparency and enables a comparability of raw material production sites (in this case aluminum production sites) and thus aims at making a contribution to the scientific field of sustainability management. Hence, it allows for practical information on environmental performances and informed purchase selection decisions in order to reduce the GHG emissions within supply chains. Practical applicability of the developed tool is enhanced by an easy integration of more up-to-date or precise data, e.g. of later reference years or, if available, of site-specific primary data. The environmental performance differences indicated in the case study do not only confirm the necessity for a site-specific evaluation in real life decision-making situations, but also show that a purchasing decision for the most efficient producer can make a crucial contribution to the reinforcement of and investment in economically viable sustainable supply chains. Finally, it can support legislation and policy development such as the EU emission trading scheme (ETS), to create even more in-depth environmental regulations, as for example an extension of the scope of $\mathrm{CO}_{2} \mathrm{e}$ emissions to mandatory upstream supply chain activities and the introduction of an emissions allocation scheme resulting from intercompany trading of intermediate products. 


\section{Appendix}

Table A. 1: Material conversion rates $[\mathrm{t} / \mathrm{t}$ ] (European Aluminium, 2013)

\begin{tabular}{lll} 
Description & Conversion rate & Notation \\
\hline Anode $\rightarrow$ Liquid aluminum & 0.440 & $\mathrm{mcr}_{p s_{1}, p s_{2}}$ \\
Liquid aluminum $\rightarrow$ Aluminum & 1.019 & $\mathrm{mcr}_{p s_{2}, p s_{3}}$ \\
Aluminum $\rightarrow$ Aluminum product & 1.004 & $\mathrm{mcr}_{p s_{3}, p s_{4}}$ \\
\hline
\end{tabular}

Table A. 2: $\quad$ Reported production volume [t / a] (BGR, 2012; Norsk Hydro ASA, 2012, 2013; TRIMET

ALUMINIUM AG, 2012; TRIMET Aluminium SE, 2013;

TRIMET SE, 2014; U.S. Geological Survey, 2013, 2015)

\begin{tabular}{lllll}
\hline $\begin{array}{l}\text { Prod. } \\
\text { site }\end{array}$ & $\begin{array}{l}\text { ANODE } \\
\text { FACTORY }\end{array}$ & $\begin{array}{l}\text { ELECTROL } \\
\text { YSIS }\end{array}$ & $\begin{array}{l}\text { CASTING } \\
\text { PLANT* }\end{array}$ & $\begin{array}{l}\text { ROLLING } \\
\text { MILL }\end{array}$ \\
\hline 1 & 115,000 & $128,047^{* *}$ & 125,659 & \\
2 & & $168,482^{* *}$ & 165,341 & \\
3 & $20,889 *$ & $50,950^{* *}$ & 50,000 & $49,801^{* *}$ \\
4 & 65,000 & $96,805^{* *}$ & 95,000 & \\
$*$ C Casting exclusively related to ingot casting (raw aluminum) of produced liquid \\
aluminum from local smelter (assumption) \\
$* *$ Calculated with material conversion rates (see Table A. 1) according to Step 1 \\
(see section 3.2.5)
\end{tabular}

Table A. 3: $\quad$ Capacities [ $\mathrm{t} / \mathrm{a}$ ] of the aluminum plants under study (BGR, 2012; Norsk Hydro ASA, 2012, 2013; TRIMET ALUMINIUM AG, 2012; TRIMET Aluminium SE, 2013; TRIMET SE, 2014; U.S. Geological Survey, 2013, 2015)

\begin{tabular}{lllll}
\hline $\begin{array}{l}\text { Prod. } \\
\text { site }\end{array}$ & $\begin{array}{l}\text { ANODE } \\
\text { FACTORY }\end{array}$ & $\begin{array}{l}\text { ELECTROL } \\
\text { YSIS }\end{array}$ & $\begin{array}{l}\text { CASTING } \\
\text { PLANT* }\end{array}$ & $\begin{array}{l}\text { ROLLING } \\
\text { MILL }\end{array}$ \\
\hline 1 & 120,000 & $\mathrm{x}$ & 133,000 \\
2 & & $\mathrm{x}$ & 175,000 & \\
3 & 50,000 & $\mathrm{x}$ & 235,000 & $\mathrm{x}$ \\
4 & 65,000 & $\mathrm{x}$ & 95,000 & \\
$\mathrm{x}=$ Facility exists on site, no specific information available \\
* Casting exclusively related to ingot casting (raw aluminum) of produced liquid \\
\multicolumn{5}{l}{} \\
\hline
\end{tabular}


Table A. 4: Reported emissions [t / a] (European Environment Agency, 2012)

\begin{tabular}{|c|c|c|c|c|c|c|}
\hline $\begin{array}{l}\text { Prod. } \\
\text { site }\end{array}$ & $\begin{array}{l}\text { Reported } \\
\text { Emissions }\left(\mathrm{CO}_{2}\right)\end{array}$ & $\begin{array}{l}\text { ANODE } \\
\text { FACTORY }\end{array}$ & $\begin{array}{l}\text { ELECTROL } \\
\text { YSIS }\end{array}$ & $\begin{array}{l}\text { CASTING } \\
\text { PLANT* }^{*}\end{array}$ & $\begin{array}{l}\text { ROLLING } \\
\text { MILL }\end{array}$ & $\begin{array}{l}\text { Reported PFC } \\
\text { Emissions }\end{array}$ \\
\hline 1 & 217,000 & $\mathrm{x}$ & $\mathrm{x}$ & $\mathrm{x}$ & & 4.67 \\
\hline 2 & 247,000 & & $\mathrm{x}$ & $\mathrm{x}$ & & 3.97 \\
\hline 3 & 136,000 & $\mathrm{x}$ & $\mathrm{x}$ & $\mathrm{x}$ & $\mathrm{x}$ & 2.13 \\
\hline 4 & 152,000 & $\mathrm{x}$ & $\mathrm{x}$ & $\mathrm{x}$ & & 1.77 \\
\hline
\end{tabular}

Table A. 5: Average emission factors $\left[\mathrm{tCO}_{2} / \mathrm{t}\right]$ per intermediate products (European Aluminium, 2013)

\begin{tabular}{ll}
\hline Process step & Emission factor \\
\hline Anode factory (anode) & $0.443^{*}$ \\
Electrolysis (liquid aluminum) & 1.574 \\
Casting plant (aluminum) & 0.113 \\
Rolling mill (aluminum product) & 0.128 \\
*Carbon dioxide from non-fuel combustion sources \\
$(0.235)+$ from fuels $(0.208)$ (World Aluminium, 2013) \\
\hline
\end{tabular}

Table A. 6: Average input factors for energy consumption $[\mathrm{kWh} / \mathrm{t}]$ (European Aluminium, 2013)

\begin{tabular}{ll}
\hline Process step & Energy consumption \\
\hline Anode factory (anode) & 108 \\
Electrolysis (liquid aluminum) & 14,880 \\
Casting plant (aluminum) & 98 \\
Rolling mill (aluminum product) & 568 \\
\hline
\end{tabular}




\section{References}

Bai, C., Sarkis, J., 2011. Evaluating supplier development programs with a grey based rough set methodology. Expert Systems with Applications 38, 13505-13517.

Beaussier, T., Caurla, S., Bellon-Maurel, V., Loiseau, E., 2019. Coupling economic models and environmental assessment methods to support regional policies: A critical review. Journal of Cleaner Production 216, 408-421.

BGR, 2012. Bericht zur Rohstoffsituation in Deutschland 2012. https://www.bgr.bund.de/DE/Themen/Min_rohstoffe/Downloads/Rohsit-2012.html. Accessed May 17, 2020.

Bieda, B., Grzesik, K., Sala, D., Gaweł, B., 2015. Life cycle inventory processes of the integrated steel plant (ISP) in Krakow, Poland - coke production, a case study. Int J Life Cycle Assess 20, 1089-1101.

Bilec, M., Ries, R., Matthews, H.S., Sharrard, A.L., 2006. Example of a Hybrid Life-Cycle Assessment of Construction Processes. J. Infrastruct. Syst. 12, 207-215.

BMWi, 2020. Energiewende in der Industrie. Potenziale und Wechselwirkungen mit dem Energiesektor. https://www.bmwi.de/Redaktion/DE/Downloads/E/energiewende-in-der-industrie-ap2abranchensteckbrief-metall.pdf?_blob=publicationFile\&v=4. Accessed June 27, 2020.

Brander, M., 2017. Comparative analysis of attributional corporate greenhouse gas accounting, consequential life cycle assessment, and project/policy level accounting: A bioenergy case study. Journal of Cleaner Production 167, 1401-1414.

Breun, P., 2016. Ein Ansatz zur Bewertung klimapolitischer Instrumente am Beispiel der Metallerzeugung und -verarbeitung. KIT Scientific Publishing, Karlsruhe.

Ciacci, L., Eckelman, M.J., Passarini, F., Chen, W.-Q., Vassura, I., Morselli, L., 2014. Historical evolution of greenhouse gas emissions from aluminum production at a country level. Journal of Cleaner Production 84, 540-549.

Das, S., 2014. Life Cycle Energy and Environmental Assessment of Aluminum-Intensive Vehicle Design. SAE Int. J. Mater. Manf. 7, 588-595.

Ecofys, ISI, Öko-Institut, 2009. Methodology for the free allocation of emission allowances in the EU ETS post 2012. Sector report for the aluminium industry. https://ec.europa.eu/clima/sites/clima/files/ets/allowances/docs/bm_study-aluminium_en.pdf. Accessed August 13, 2020.

Ecoinvent, 2007-2013. ecoinvent Data V2.2. The life cycle inventory data version. Swiss Centre for Life Cycle Inventories, St. Gallen.

Egede, P., 2016. Environmental Assessment of Lightweight Electric Vehicles. Springer International Publishing.

EPA, 2016. U.S. Greenhouse Gas Inventory Report: 1990-2014, Washington.

EPSC, 2016. Towards low-emission mobility. Driving the modernisation of the EU economy. European Political Strategy Centre, Brussels.

European Aluminium, 2013. Environmental Profile Report for the European Aluminium Industry Data for the year 2010. Life-Cycle inventory data for aluminium production and transformation processes in Europe. https://european-aluminium.eu/media/1329/environmental-profile-report-for-the-europeanaluminium-industry.pdf. Accessed May 13, 2020. 
European Aluminium, 2019. Environment. A culture of responsibility. https://www.europeanaluminium.eu/policy-areas/environment/. Accessed June 2, 2020.

European Commission, 2006. Regulation (EC) No 166/2006. Official Journal of the European Union L33, $1-17$.

European Commission, 2009. Regulation (EC) No 443/2009. Official Journal of the European Union L140, 1-15.

European Commission, 2010. Directive 2010/75/EU of the European Parliament and of the Council of 24 November 2010 on industrial emissions (integrated pollution prevention and control). Official Journal of the European Union L334, 17-119.

European Commission, 2014. Best available techniques (BAT) reference document for the non-ferrous metals industries. Industrial Emissions Directive 2010/75/EU (integrated pollution prevention and control). Final Draft. Publications Office of the European Union, Luxembourg.

European Commission, 2015. Paris Agreement. Policy. https://ec.europa.eu/clima/policies/international/negotiations/paris_en\#tab-0-0. Accessed May 1, 2020.

European Commission, 2017. Best available techniques (BAT) reference document for the non-ferrous metals industries. Industrial Emissions Directive 2010/75/EU (integrated pollution prevention and control). Publications Office of the European Union, Luxembourg.

European Commission, 2019a. EU transport in figures - Statistical pocketbook 2019. Statistical pocketbook 2019. Publications Office of the European Union, Luxembourg.

European Commission, 2019b. Regulation (EU) 2019/631. Official Journal of the European Union L111.

European Environment Agency, 2012. The European Pollutant Release and Transfer Register (E-PRTR), Member States reporting under Article 7 of Regulation (EC) No 166/2006. Database.

European Environment Agency, 2018. CO2 emission intensity. Electricity generation - CO2 emission intensity European Union. https://www.eea.europa.eu/data-and-maps/daviz/co2-emission-intensity5/download.table. Accessed May 23, 2020.

European Environment Agency, 2019a. EMEP/EEA air pollutant emission inventory guidebook 2019:. 2.C.3 Aluminium production. https://www.eea.europa.eu/publications/emep-eea-guidebook-2019/partb-sectoral-guidance-chapters/2-industrial-processes/2-c-metal-production/2-c-3-aluminiumproduction/view. Accessed March 5, 2020.

European Environment Agency, 2019b. Greenhouse gas emissions from transport in Europe. Indicator Assessment.

Farjana, S.H., Huda, N., Mahmud, M.A.P., 2019. Impacts of aluminum production: A cradle to gate investigation using life-cycle assessment. The Science of the total environment 663, 958-970.

Gabi, 2017. Version 8.1. GaBi software-System and Database for Life Cycle Engineering. Thinkstep, A.G., Leinfelden-Echterdingen.

Gautam, M., Pandey, B., Agrawal, M., 2018. Carbon Footprint of Aluminum Production, in: Muthu, S.S. (Ed.), Environmental carbon footprints. Industrial case studies. Butterworth-Heinemann an imprint of Elsevier, Kidlington, Oxford, United Kingdom, pp. 197-228.

GDA, 2015. Aluminium im Verkehrswesen: Mit Leichtigkeit bewegen. http://www.aluinfo.de/mobilitaet.html. Accessed May 1, 2020. 
GHG Protocol, 2004. The Greenhouse Gas Protocol. A Corporate Accounting and Reporting Standard. https://ghgprotocol.org/sites/default/files/standards/ghg-protocol-revised.pdf. Accessed April 29, 2020.

GHG Protocol, 2013. Corporate Value Chain (Scope 3) Accounting and Reporting Standard. Supplement to the GHG Protocol Corporate Accounting and Reporting Standard. https://ghgprotocol.org/sites/default/files/standards/Corporate-Value-Chain-Accounting-ReporingStandard_041613_2.pdf. Accessed April 29, 2020.

Guinée, J.B., Heijungs, R., Huppes, G., Zamagni, A., Masoni, P., Buonamici, R., Ekvall, T., Rydberg, T., 2011. Life cycle assessment: past, present, and future. Environmental science \& technology 45, 90-96.

Guinée, J.B., Heijungs, R., Udo de Haes, H.A., Huppes, G., 1993. Quantitative life cycle assessment of products. Journal of Cleaner Production 1, 81-91.

Hartley, J.L., Choi, T.Y., 1996. Supplier development. Customers as a catalyst of process change. Business Horizons 39, 37-44.

Hendrickson, C.T., Horvath, A., Joshi, S., Klausner, M., Lave, L.B., McMichael, F.C., 1997. Comparing two life cycle assessment approaches. A process model vs. economic input-output-based assessment, in: Proceedings of the 1997 IEEE International Symposium on Electronics and the Environment, ISEE, 1997. May 5-7, 1997, San Francisco, California. Institute of Electrical and Electronics Engineers; Available from IEEE Service Center, [New York, N.Y.], Piscataway, N.J., pp. 176-181.

International Standards Organisation, 2006a. ISO 14040: Environmental management - Life cycle assessment - Principles and framework, Geneva.

International Standards Organisation, 2006b. ISO 14044: Environmental management - Life cycle assessment - Requirements and Guidelines, Geneva.

IPCC, 2007. Climate change 2007: The Physical Science Basis. Contribution of Working Group I to the Fourth Assessment Report of the Intergovernmental Panel on Climate Change. Cambridge University Press, Cambridge.

IPCC, 2013. Climate change 2013: The Physical Science Basis. Contribution of Working Group I to the Fifth Assessment Report of the Intergovernmental Panel on Climate Change. Cambridge University Press, Cambridge.

IPCC, 2014. Climate Change 2014: Mitigation of Climate Change. Contribution of Working Group III to the Fifth Assessment Report of the Intergovernmental Panel on Climate Change. Cambridge University Press, Cambridge.

Kndungu, P., Molavi, J.M., 2014. A Hybrid LCA Approach to Quantify the Environmental Impacts during Construction. IJIRSET 03, 16402-16413.

Kornelíusdóttir, A.M., 2014. A cradle-to-gate life cycle assessment of primary aluminium production at Norðurál. University of Iceland, Reykjavik, Iceland.

Kovács, V.B., Kiss, L., 2016. Comparative Analysis of the Environmental Impacts of Aluminum Smelting Technologies, in: Hyland, M. (Ed.), Light Metals 2015. Springer International Publishing, Cham, s.1., pp. 529-534.

Leontief, W., 1970. Environmental Repercussions and the Economic Structure: An Input-Output Approach. The Review of Economics and Statistics 52, 262.

Lieberwirth, H., Krampitz, T., 2015. Entwicklungstendenzen für den Einsatz von Leichtbauwerkstoffen im Fahrzeugbau und Auswirkungen auf das Recycling. Recycling und Rohstoffe, 208-218. 
Liu, G., Müller, D.B., 2012. Addressing sustainability in the aluminum industry: a critical review of life cycle assessments. Journal of Cleaner Production 35, 108-117.

Norgate, T.E., Jahanshahi, S., Rankin, W.J., 2007. Assessing the environmental impact of metal production processes. Journal of Cleaner Production 15, 838-848.

Norsk Hydro ASA, 2012. Annual Report - 2012. https://www.hydro.com/en/investors/reports-andpresentations/quarterly-reports/previous-reports/. Accessed May 17, 2020.

Norsk Hydro ASA, 2013. Annual Report - 2013. https://www.hydro.com/en/investors/reports-andpresentations/quarterly-reports/previous-reports/. Accessed May 17, 2020.

Nunez, P., Jones, S., 2016. Cradle to gate: life cycle impact of primary aluminium production. Int J Life Cycle Assess 21, 1594-1604.

Paraskevas, D., Kellens, K., van de Voorde, A., Dewulf, W., Duflou, J.R., 2016. Environmental Impact Analysis of Primary Aluminium Production at Country Level. Procedia CIRP 40, 209-213.

Roy, P., Nei, D., Orikasa, T., Xu, Q., Okadome, H., Nakamura, N., Shiina, T., 2009. A review of life cycle assessment (LCA) on some food products. Journal of Food Engineering 90, 1-10.

Schiessl, A., Müller, R., Volk, R., Zimmer, K., Breun, P., Schultmann, F., 2020. Integrating site-specific environmental impact assessment in supplier selection: exemplary application to steel procurement. Journal of Business Economics 27, 1-49.

Schmid, D., Zur-Lage, L., 2014. Perspektiven für das Recycling von Altfahrzeugen. Recycling und Rohstoffe 7, 105-126.

Schmidt, J., Thrane, M., 2009. Life cycle assessment of aluminium production in new Alcoa smelter in Greenland. Government of Greenland, Greenland.

Sonnemann, G., Castells, F., Schuhmacher, M., 2004. Integrated life-cycle and risk assessment for industrial processes. Lewis Publishers, Boca Raton FL.

Suciati, A., Goto, N. (Eds.), 2014. Environmental Impact Assessment of the Development of Primary Aluminium Industry in Indonesia based on MFA and LCA as a Baseline Study to Achieve Sustainable Industry, 70th ed. IACSIT Press, Singapore.

Suh, S., Lenzen, M., Treloar, G.J., Hondo, H., Horvath, A., Huppes, G., Jolliet, O., Klann, U., Krewitt, W., Moriguchi, Y., Munksgaard, J., Norris, G., 2004. System Boundary Selection in Life-Cycle Inventories Using Hybrid Approaches. Environ. Sci. Technol. 38, 657-664.

Tan, R.B.H., Khoo, H.H., 2005. An LCA study of a primary aluminum supply chain. Journal of Cleaner Production 13, 607-618.

The Federal Government, 2019. CO2-Bepreisung. https://www.bundesregierung.de/bregde/themen/klimaschutz/co2-bepreisung-1673008. Accessed April 25, 2020.

Totten, G.E., Mackenzie, D.S., 2003. Handbook of Aluminum: Volume 2: Alloy Production and Materials Manufacturing. Marcel Dekker, Inc, New York.

TRIMET ALUMINIUM AG, 2012. Geschäftsbericht 2012. https://www.trimet.eu/de/geschaeftsberichte/trimet_geschaeftsbericht_2012.pdf. Accessed May 17, 2020.

TRIMET Aluminium SE, 2013. Geschäftsbericht 2013. https://www.trimet.eu/de/geschaeftsberichte/trimet_geschaeftsbericht_2013.pdf. Accessed May 17, 2020. 
U.S. Geological Survey, 2013. Area reports - International - Europe and Central Eurasia: U.S. Geological Survey Minerals Yearbook 2011. U.S. Government Printing Office.

U.S. Geological Survey, 2015. Area reports - International - Europe and Central Eurasia: U.S. Geological Survey Minerals Yearbook 2012. U.S. Government Printing Office.

U.S. Geological Survey, 2020. Bauxite and Alumina Data Sheet. Mineral Commodity Summaries 2020. https://pubs.usgs.gov/periodicals/mcs2020/mcs2020-bauxite-alumina.pdf. Accessed March 11, 2020.

UBA, 2019a. Emissionen aus Betrieben der Metallindustrie. https://www.umweltbundesamt.de/daten/umwelt-wirtschaft/industrie/emissionen-aus-betrieben-dermetallindustrie\#emissionen-aus-eisenmetallgiessereien. Accessed May 25, 2020.

UBA, 2019b. Entwicklung der spezifischen Kohlendioxid-Emissionen des deutschen Strommix in den Jahren 1990 - 2018. https://www.umweltbundesamt.de/sites/default/files/medien/1410/publikationen/2019-04-10_cc_102019_strommix_2019.pdf. Accessed May 23, 2020.

Volkswagen AG, 2019. Volkswagen ID. will be a pioneer of sustainable mobility. www.volkswagennewsroom.com/en/press-releases/volkswagen-id-will-be-a-pioneer-of-sustainable-mobility-4649. Accessed May 13, 2019.

Weidema, B.P., 1993. Market aspects in product life cycle inventory methodology. Journal of Cleaner Production 1, 161-166.

Weidema, B.P., 2003. Market information in life cycle assessment. Miljøstyrelsen.

WMV, 2019. Metallstatistik 2018. https://www.wvmetalle.de/presse/allepublikationen/artikeldetail/?tx_artikel_feartikel\%5Bartike1\%5D=6877\&tx_artikel_feartikel\%5Baction $\% 5 \mathrm{D}=$ show. Accessed May 2, 2020.

World Aluminium, 2016. Results of the 2015 Anode Effect Survey. Report on the Aluminium Industry's Global Perfluorocarbon Gases Emissions. http://www.worldaluminium.org/media/filer_public/2016/08/08/2015_anode_effect_survey_result_2016.pdf. Accessed May 13, 2020.

World Bureau of Metal Statistics, 2019a. Production of refined primary aluminum in Europe from 2009 to 2018. (in 1,000 metric tons). In Statista - The Statistics Portal. https://www.statista.com/statistics/1027597/europe-primary-aluminum-production/. Accessed March 4, 2020.

World Bureau of Metal Statistics, 2019b. Production of secondary aluminum in Europe from 2009 to 2018. (in 1,000 metric tons). In Statista - The Statistics Portal. https://www.statista.com/statistics/1028859/europe-secondary-aluminum-production/. Accessed March 4, 2020.

Yang, Y., Guo, Y.Q., Zhu, W.S., Huang, J.B., 2019. Environmental impact assessment of China's primary aluminum based on life cycle assessment. Transactions of Nonferrous Metals Society of China 29, 1784-1792.

Yellishetty, M., Mudd, G.M., Ranjith, P.G., Tharumarajah, A., 2011. Environmental life-cycle comparisons of steel production and recycling. Sustainability issues, problems and prospects. Environmental Science \& Policy 14, 650-663.

Zamagni, A., Pesonen, H.-L., Swarr, T., 2013. From LCA to Life Cycle Sustainability Assessment. Concept, practice and future directions. Int J Life Cycle Assess 18, 1637-1641. 
Zimmer, K., Fröhling, M., Breun, P., Schultmann, F., 2017. Assessing social risks of global supply chains: A quantitative analytical approach and its application to supplier selection in the German automotive industry. Journal of Cleaner Production 149, 96-109. 